\title{
ANÁLISE ECONÔMICA DE INVESTIMENTO EM RENOVAÇÃO DE CACAU: UM ESTUDO DE CASO
}

\author{
EBIESEL NASCIMENTO ANDRADE FILHO
}

Orientador: Dr. EVARISTO MARZABAL NEVES

Dissertação apresentada à Escola Superior de Agricultura "Luiz de Queiroz", da Universidade de São Paulo, para obtenção do título de Mestre em "Economia Agrária".

PIRACICABA

Estado de São Paulo - Brasil

1981 
Ao meu pai, in memorian

A minha māe, por tudo

A meu filho Thiago, pela minha ausência 


\title{
A GR A DECI MENTOS
}

\begin{abstract}
Apresentamos nossos sinceros agradecimentos a todas as pessoas e instituiçoes que contribuiram para a reali zaçao deste trabalho:
\end{abstract}

$\overline{\mathrm{A}}$ Comissão Executiva do Plano da Lavoura Cacaueira - CEPLAC

Ao Departamento de Economia e Sociologia Rural da Escola Su perior de Agricultura "Luiz de Queiroz" da Universidade de São Paulo, seus professores e funcionários;

Ao Prof. Dr. Evaristo Marzabal Neves, pela orientação e ami $\mathrm{z}$ ade ;

Ao Prof. Dr. Rodolfo Hoffmann, pela ajuda na computação dos dados básicos;

Aos Prof S. José Ferreira de Noronha, Cicely Moutinho Amaral, e ao Dr. Ricardo Rodolfo Tafani, pelas sugestões e críti cas apresentadas a esta dissertação;

A meus irmãos Nicolau e Eliana, pelo constante estímulo, a mizade e compreensão;

Aos Colegas de estudo, Aureo Brandão, Luiz Artur, Maria Bri gida e Hiroshige Okawa, pela solidariedade e amizade. 


\section{N D I C E}

Pàg .

LISTA DOS QUADROS ......................... v

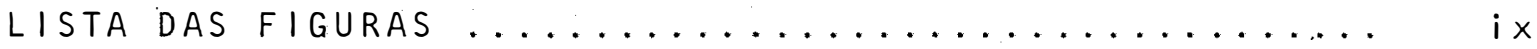

LISTA DOS ANEXOS .......................

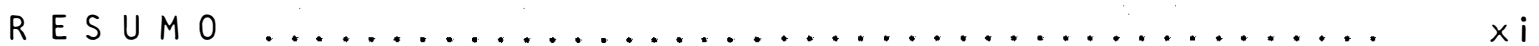

$S \cup M M A R Y \ldots \ldots \ldots \ldots \ldots \ldots \ldots \ldots \ldots \ldots \ldots \ldots \ldots \ldots \ldots \ldots \ldots$

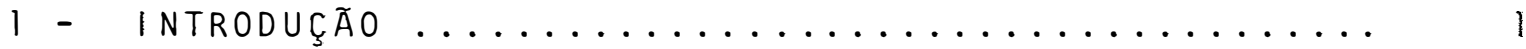

1.1 - 0 Problema e sua Importāncia ............ I

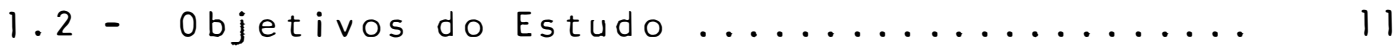

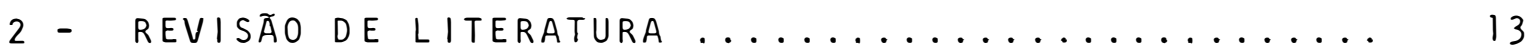

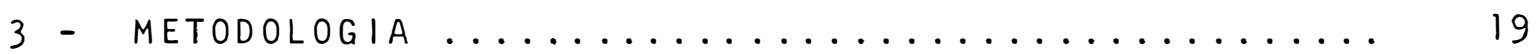

3.1 - A Técnica da Fazenda Unitäria......... 19

3.2 - A Fazenda Unitäria do CEPEC ........... 20

3.3 - Considerações Teóricas sobre Investimen tos em Renovação de Cacau .............. 23

3.4 - Avaliação de Investimento em Renovação de

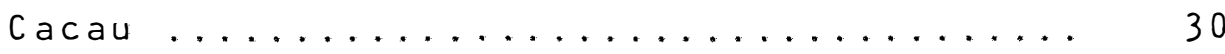

3.4 .1 - Critério do valor atual ...... 32

3.4.2 - Critério da taxa interna de re

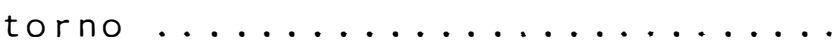


3.4.3 - Limitações dos Critērios de Ava 1 i ação ci tados ............. 35

3.5 - Fonte dos Dados .................. 37

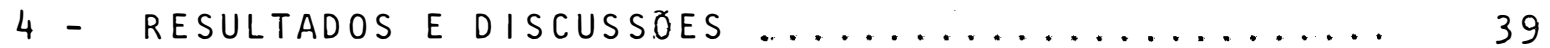

4.1 - Produtividade e Ciclo de Produção Consi derado ...................... 40

4.2 - Estimativa da Receita Bruta por Hectare.. 47.

4.3 - Estimativa do Custo de Renovação por Hec

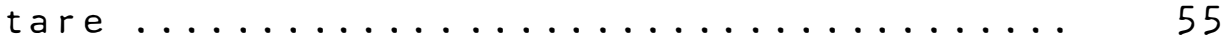

4.4 - Estimativa da Receita Líquida por Hecta

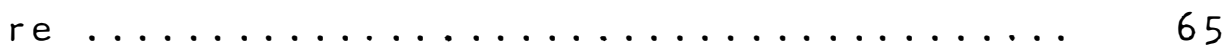

4.5 - Valor Atual da Receita Líquida Estimada.. 70

4.6 - Taxas Internas de Retornos Estimadas .... 73

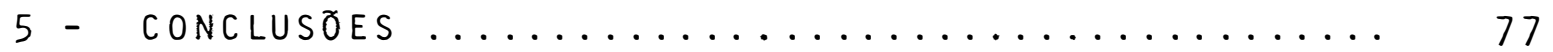

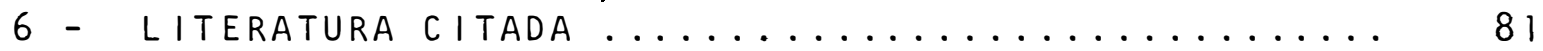

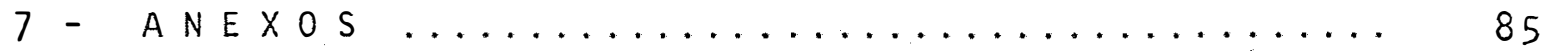




\section{LISTA DOS QUADROS}

Pàg .

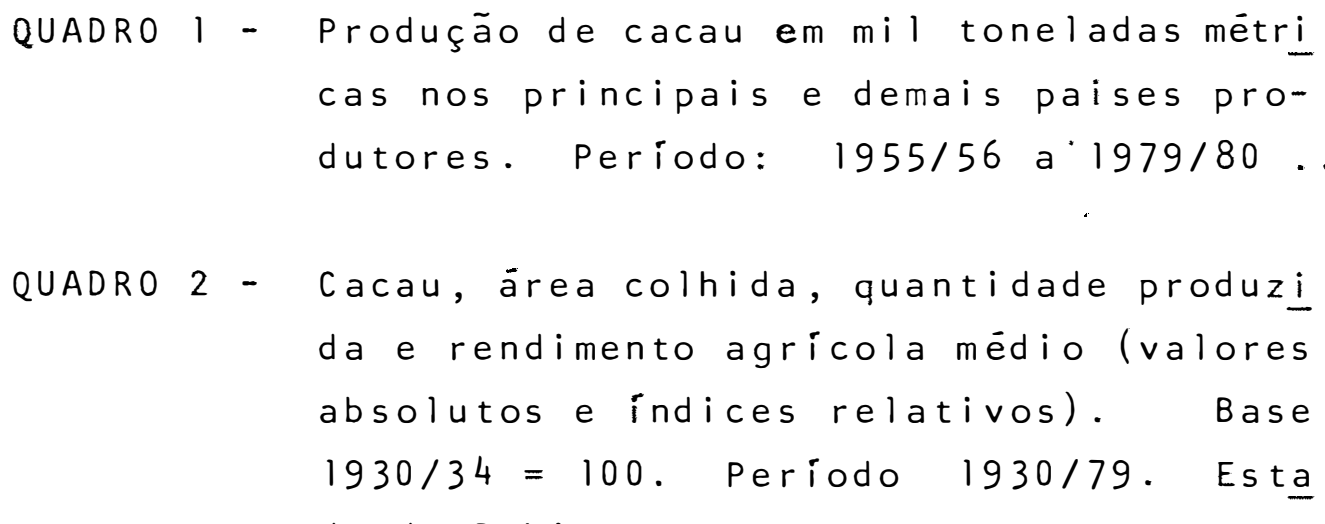

do da Bahia .................... 4

QUADRO 3 - Evolução anual da ārea trabalhada, em hectares, nas práticas recomendadas pela CEPLAC. Período: 1965 a 1979. Re-

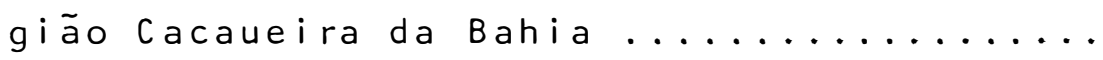

QUADRO 4 - Metas programadas e alcançadas, em hectares, pelo programa de renovação de ca cauais do Estado da Bahia no Período de 1976/80. (Valores anuais e acumulados) ...

QUADRO 5 - Produção de cacau esperada, em arrobas por hectare, nos blocos renovados pelo "Método de Derruba Total", considerando-

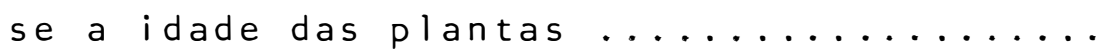

QUADRO 6 - Produção de cacau esperada, em arrobas por hectare, nos blocos renovados pelo "Método sob Cacaueiros Decadentes", con siderando-se a idade das plantas ........ 45 
QUADRO 7 - Receita bruta estimada, em cruzeiros por hectare, nos blocos renovados pelo "Método de Derruba Total", considerando-se

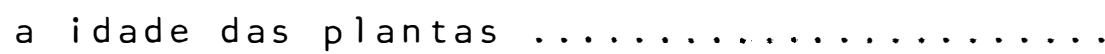

QUADRO 8 - Receita bruta estimada, em cruzeiros por hectare, nos blocos renovados pelo "Método sob Cacaueiros Decadentes", considerando-se a idade das plantas ..........

QUADRO 9 - Estimativa da perda de receita líquida por hectare no Bloco l, decorrente da queda de produção pelo corte do cacaual de cadente, durante a fase inicial do pro-

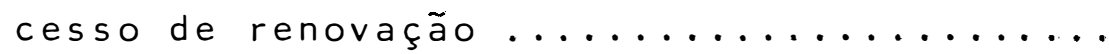

QUADRO 10 - Estimativa da perda de receita. líquida por hectare no Bloco 6, decorrente da queda de produção pelo corte do cacaual decadente, durante a fase inicial do pro cesso de renovação ..................

QUADRO II - Estimativa da perda de receita líquida por hectare no Bloco 8 , decorrente da queda de produção pelo corte do cacaual decadente, durante a fase inicial do pro

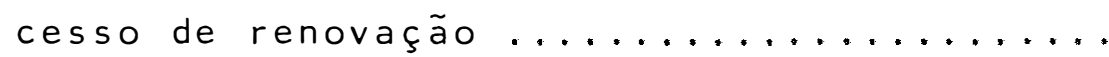


Pàg.

QUADRO 12 - Estimativa da perda de receita líquida por hectare no Bloco 3 , decorrente da queda de produção pelo corte do cacaual decadente, durante a fase inicial do pro cesso de renovação $\ldots \ldots \ldots \ldots \ldots \ldots \ldots \ldots$

QUADRO 13 - Estimativa da perda de receita líquida por hectare no Bloco 7 , decorrente da queda de produção pelo corte do cacaual decadente, durante a fase inicial do pro

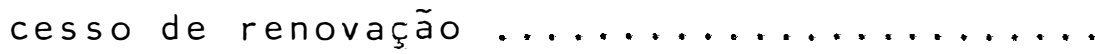

QUADRO 14 - Custo estimado, em cruzeiros por hectare, nos blocos renovados pelo "Método de Derruba Total", considerando-se a idade

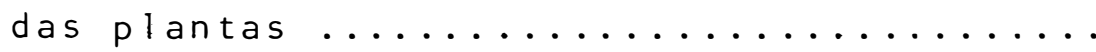

QUADRO 15 - Custo estimado, em cruzeiros por hectare, nos blocos renovados pelo "Método sob Cacaueiros Decadentes", consideran-

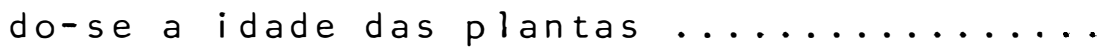

QUADRO 16 - Receita líquida estimada, em cruzeiros por hectare, nos blocos renovados pelo "Método de Derruba Total", consideran-

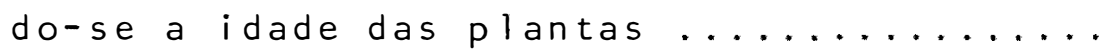

QUADR0 17 - Receita líquida estimada, em cruzeiros por hectare, nos blocos renovados pelo "Método sob Cacaueiros Decadentes", con siderando-se a idade das plantas ......... 
$v i i i$

Pàg.

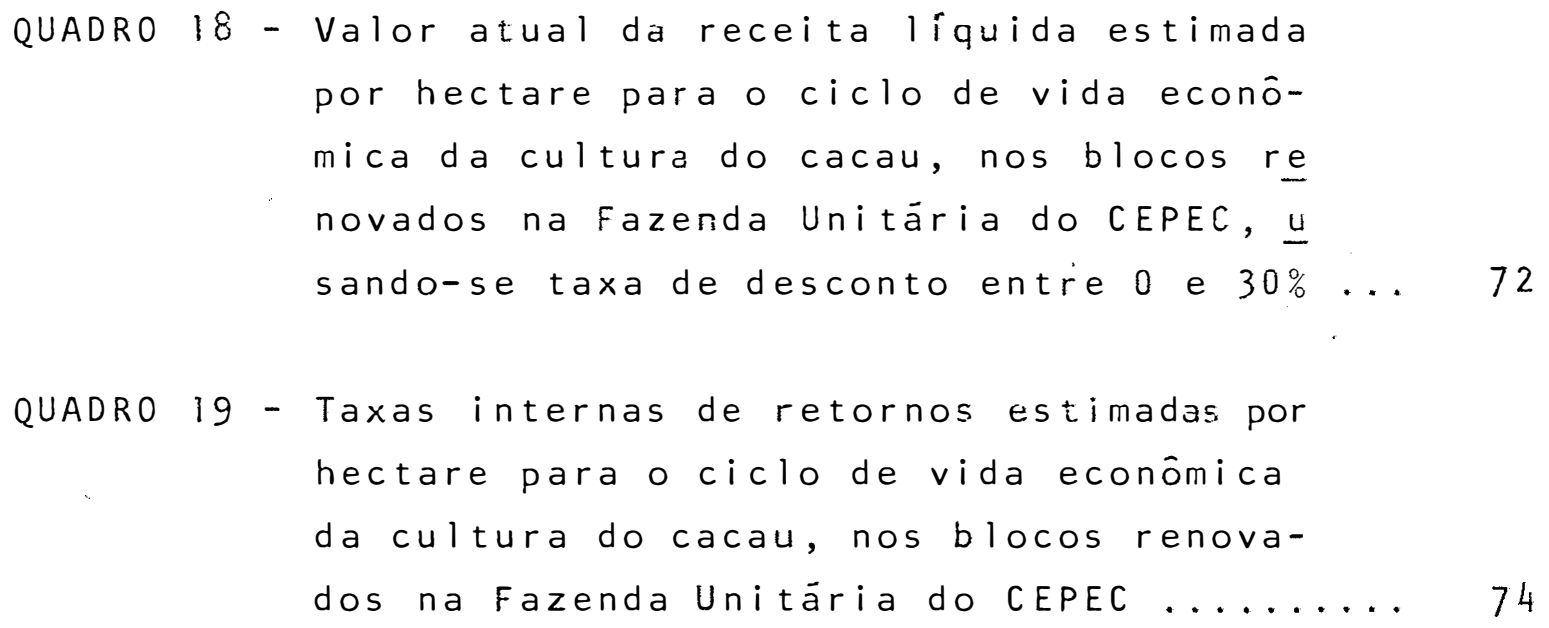




\section{LISTA DE FIGURAS}

FIGURA I - Levantamento detalhado dos Solos da area do CEPEC ....................... 21

FIGURA 2 - Comportamento hipotético de fluxos descontados de receita bruta e custos no

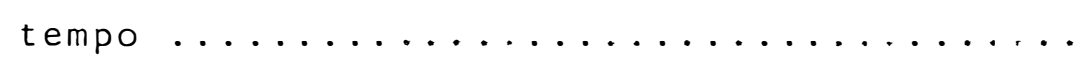

FIGURA 3 - Comportamento hipotético da receita brü ta (RT) e custos de implantação e manu tenção da cultura de cacau (CT), ao lon go do tempo, para uma unidade de ärea, quando se usa o método de renovação com

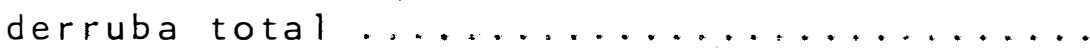

FIGURA 4 - Comportamento hipotético da receita brü ta (RT) e custos de implantação e manutenção da cultura de cacau (CT), ao longo do tempo, para uma unidade de área, quando se usa o método de renova ção sob cacaueiros decadentes ........... 


\section{LISTA DE ANEXOS}

Pāg .

ANEXO 1 - Preço médio recebido pelo produtor de ca cau no período 1970 a 1980. Todos os va lores foram corrigidos utilizando-se o Indice Geral de Preços da Fundação Getú lio Vargas, com base em $1980=100 \ldots . \ldots 6$

ANEXO 2 - Preço diārio da mão-de-obra no período de 1970 a 1980. Todos os valores foram corrigidos utilizando-se o rndice Geral de Preços da Fundação Getūlio Vargas, combase em $1980=100 \ldots \ldots \ldots \ldots \ldots$

ANEXO 3 - Preço médio anual dos principais insumos usados na Fazenda Uni tāria do CEPEC no período de 1970 a 1980. Valores corrigidos utilizando-se o rndice Geral de Preços da Fundação Getūlio Vargas, com base em $1980=100 \ldots \ldots \ldots \ldots \ldots \ldots$

ANEXO 4 - Coeficientes técnicos necessärios para manutenção anual de um hectare de cacaueiros safreiros nos blocos renovados pelo "Método de Derruba Total" .........

ANEXO 5 - Coeficientes técnicos necessários para manutenção anual de um hectare de cacaueiros safreiros nos blocos renovados pelo "Método sob Cacaueiros Decadentes" ... 


\section{RES U M 0}

O crescimento da produtividade dos cacauais de cadentes decorrente do uso de tecnologia químico-biológica di ficilmente poderá manter-se por longo tempo devido a idade avançada das plantações de cacau no Estado da Bahia.

A longo prazo, para continuar com uma cultura economicamente viāvel, existe a necessidade de renovar os veThos cacauais, substituindo essas plantações por outras mais produtivas desenvolvidas pelas pesquisas genéticas realizadas no CEPEC.

Este estudo tentou mensurar e comparar a renta bilidade de dois métodos de renovação de cacauais que vem sen do investigados pelo Centro de Pesquisas do Cacau, atravēs da Técnica da Fazenda Unitāria. 
Os dados foram provenientes de anotações contā beis da Fazenda Unitāria do CEPEC, tendo-se utilizado simulações para obter séries temporais de produção e custos.

As anāijses permitiram concluir que tanto à cri tério do valor atual como o critério da taxa interna de retor no conduziram a resultados semelhantes na avaliação e seleção de projetos de investimento em renovação de cacauais.

Através do critērio do valor atual verificou-se que a taxa mínima de remuneração ao capital investido em reno vação de cacau situou-se em torno de $12,5 \%$ a.a. e a mäxima em torno de $27 \%$ a.a.

A alternāncia verificada na seleção e ordena ção dos projetos pareceu estar associada ao nîvel de produtividade alcançada em cada bloco devido as diferenças de drenagem e fertilidade dos solos, pois o montante de recursos apli cados durante o período inicial do processo foi equivalente pa ra ambos os mētodos de renovação.

As variaçöes sucessivas de sinal apresentada pe la diferença entre os fluxos de caixa de dois projetos homōlo gos, o que resulta em mūitiplas taxas internas de retorno, não permitiu selecionar a melhor alternativa de investimento em re novação de cacau através da taxa interna de retorno sobre os custos de FISHER. 
$x i \mathrm{i}$.

\section{$S \cup M M A R Y$}

The increasing of the productivity of the cocoa plantations, which are decadent because of the use of chemical and biological techniques, will hardly be maintained for a long time, due to the plant aging of the plantations in the State of Bahia, Brazil. In order to keep the crop economically viable there exists the need to renew the old plantations by replacing them for more productive ones which were developed by the genetic research done at the Cocoa Research Center ("Centro de Pesquisas do Cacau - CEPEC"). This paper deals with the measurement and comparison of the profitability of two methods of renewal of cocoa plantations that are being investigated by the Cocoa Research Center through the techniques of the Unitary Farm. The data were derived from the 
accountancy section of the Unitary Farm of CEPEC and simulations were used for obtaining the temporal series of yield and costs. The analysis allowed one to conclude that the criterion of current value, as well as the criterion of internal rate of return led to similar results in the evaluation and selection of the projects of cocoa plantation renewal. Through the criterion of current value it was observed that the minimal rate of rewarding of the capital invested in cocoa renewal was around 12.5 per cent a year, and the maximum was around 27.0 per cent a year. The alternancy observed in the selection and ordering of the projects seemed to be associated to the level of productivity reached in each block, due to the differences in soil drainage and fertility, because the amount of resources ployed during the initial period of the process was equivalent for both methods of renewal. The change of sign showed by the difference between the cash flows of two homologous projects resulted in multiple internal rate of return and did not permit one to select the best alternative of investment concerning the cocoa renewal through the internal rate of return over the costs of FISHER. 


\section{1 - INTRODUCÃO}

\section{1 - 0 Problema e sUa IMPORTÂNCIA}

A exploração do cacau no Brasil, até meados do século XVII, constituia apenas uma atividade extrativa. Seu cultivo iniciou-se por volta de 1679 no Estado do Pará, onde sua expansão sofreu sērias limitações devido, entre outras coi sas, a falta de seleção na escolha dos solos, além do sistema rudimentar de exploração que se verificava naquela região.

o cacau foi introduzido na Bahia em 1746 ao lon go das margens do Rio Pardo, expandindo-se daí por toda Região Sul, tornando-se o principal suporte econômico do Estado ao final do século passado, ALVIN e ROSÁRlO (1972).

No início do presente sēculo verificou-se acrës cimos constantes e sucessivos na produção brasileira, atingin do ao final do período $1930 / 40$ uma média anual aproximada de 
140.000 toneladas de amendoas de cacau, TAFANI (1976).

As exportações de cacau sempre constituiram uma relevante fonte de divisas para o país. No final da década de cinquenta o cacau ocupava o segundo lugar em receitas cambiais provenientes das exportações brasileiras, sendo supe rado apenas pelo café, MONTEIRO (1976).

Atualmente o cacau é produzido em pouco mais de trinta países, dos quais, cinco (Gana, Nigēria, Costa do Marfim, República Unida dos. Camarões e Brasill foram responsāveis por aproximadamente $77 \%$ da produção mundial nos últimos 25 anos. A concentração da produção mundial de cacau nesses cinco países se deu, principalmente, por força das condições climáticas e pela disponibilidade de solos adequados ao culti vo.

Nos últimos vinte anos a produção de cacau em Camarões permaneceu praticamente estável, enquanto as produções de Gana e Nigēria sofreram um lento processo de decadência, ao contrário do que ocorreu com o Brasil e Costa do Marfim que quase triplicaram as suas produções no período considerado (Quadro 1).

MONTEIRO (1976), analisando o desempenho da lavoura cacaueira da Bahia, responsável por aproximadamente $95 \%$ da produção brasileira de cacau, verificou que seus rendimentos decresceram a partir do quinquênio $1935 / 39$ até o de 1960/64. 
QUADRO 1 - Produção de cacau em mil toneladas métricas nos principais e demais países produtores. Período: $1955 / 56$ a $1979 / 80$

\begin{tabular}{|c|c|c|c|c|c|}
\hline Países & $\begin{array}{c}1955 / 56 \\
a \\
1959 / 60\end{array}$ & $\begin{array}{c}1960 / 61 \\
a \\
1964 / 65\end{array}$ & $\begin{array}{c}1965 / 66 \\
a \\
1969 / 70\end{array}$ & $\begin{array}{c}1970 / 71 \\
a \\
1974 / 75\end{array}$ & $\begin{array}{c}1975 / 76 \\
a \\
1979 / 80\end{array}$ \\
\hline \multicolumn{6}{|c|}{ (em mil toneladas métricas) } \\
\hline Camarões & 66 & 80 & 93 & 114 & 101 \\
\hline Gama & 258 & 459 & 392 & 403 & 311 \\
\hline Costa do Marfim & 61 & 105 & 147 & 208 & 274 \\
\hline Nigēria & 121 & 218 & 221 & 246 & 178 \\
\hline Bras i 1 & 173 & 120 & 172 & 203 & 275 \\
\hline Equador & 33 & 44 & 59 & 67 & 74 \\
\hline Demais Países & 177 & 222 & 238 & 265 & 264 \\
\hline Total mundial & 889 & 1.248 & 1322 & 1.506 & 1.477 \\
\hline
\end{tabular}

Embora tenha ocorrido expansão de $194 \%$ na ärea colhida no período de 1930 a 1964, este acréscimo da ärea pró porcionou aumento de apenas $65 \%$ na produção gerando, em conse quéncia, substancial declínio nos rendimentos físicos por uni dade de àrea.

A partir de 1960 , verificou-se que a àrea coIhida sofreu um ligeiro decréscimo, enquanto a produção cont nou crescendo em decorrência da recuperação dos rendimentos (Quadro. 2). A elevação desta produtividade se deveu, em boa 
parte, a política implementada pela CEPLAC (Comissão Executiva do Plano da Lavoura Cacaueira) para as äreas de pesquisa e extensão rural conforme se registrará a seguir.

QUADRO 2 - Cacau, ärea colhida, quantidade produzida e rendi mento agrícola médio (valores absolutos e indices relativos). Base 1930/34=100. Período 1930/79. Estado da Bahia

\begin{tabular}{cccccccc}
\hline \multirow{2}{*}{$\begin{array}{c}\text { Quinque- } \\
\text { nio }\end{array}$} & \multicolumn{2}{c}{ Area colhida } & \multicolumn{2}{c}{ Quantidade produzida } & \multicolumn{2}{c}{ Rendimento } \\
\cline { 2 - 7 } & Ha & & Tndice & Toneladas & Tndice & kg/ha & Tndice \\
\hline $1930 / 34$ & 151.104 & 100 & 86.494 & 100 & 576 & 100 \\
$1935 / 39$ & 173.714 & 115 & 123.074 & 142 & 709 & 123 \\
$1940 / 44$ & 226.357 & 150 & 127.680 & 147 & 564 & 98 \\
$1945 / 49$ & 240.269 & 159 & 113.707 & 131 & 473 & 82 \\
$1950 / 54$ & 290.581 & 192 & 132.144 & 153 & 454 & 79 \\
$1955 / 59$ & 388.216 & 257 & 156.724 & 181 & 404 & 70 \\
$1960 / 64$ & 444.350 & 294 & 143.372 & 166 & 323 & 56 \\
$1965 / 69$ & 425.993 & 282 & 169.661 & 196 & 398 & 69 \\
$1970 / 74$ & 401.546 & 266 & 196.370 & 227 & 489 & 85 \\
$1975 / 79$ & 403.322 & 267 & 245.197 & 283 & 607 & 105 \\
\hline
\end{tabular}

FONTE: $\quad$ MONTEIRO (1976).

Em 1964 a CEPLAC criou O Departamento de Exten são (DEPEX) para divulgar e acelerar o processo de adoção, jun 
to aos agricultores, de técnicas pesquisadas pelo Centro de Pesquisas do Cacau (CEPEC), visando o aumento da produtividade, TAFANI (1976).

o período de 1964 a 1969 destinou-se à monta gem de uma infra-estrutura operacional, com o objetivo de pos sibilitar ao Departamento de Extensão a utilização de melhores métodos de ação junto aos agricultores.

As metas alcançadas nas diferentes práticas rẹ comendadas pela CEPLAC tais como, fertilização, pulverização, aplicação de inseticidas e outras, mostram que os insumos modernos usados nos cacauais foram os principais responsáveis pe la recuperação da produtividade no período considerado (Quadro 3 ).

Pesquisas realizadas por MENEZES (1972) indicam que o crescimento da produtividade dos cacauais decadentes, p $\underline{e}$ lo uso intensivo de tecnologias do tipo químico-biológico, pạ rece ter sido favorecido pela relação entre os preços do produto e dos insumos, o que levou os agricultores a pensar que ganhos adicionais poderiam ser obtidos aplicando-se insumos mo dernos em cacauais que eram antieconômicos antes da aplicação de tais insumos.

Por outro lado, TAFAN! (1976) argumenta que os beneficios adicionais obtidos a partir de aumento nos rendi mentos de cacauais de baixa produtividade, pelo uso de insumos modernos, dificilmente poderä manter-se por longo tempo devi- 
do a idade avançada das plantações de cacau no Estado da Bahia.

QUADRO 3 - Evolução anual da ārea trabalhada, em hectares, nas pràticas recomendadas pela CEPLAC. Período: 1965 a 1979. Região cacaueira da Bahia

\begin{tabular}{|c|c|c|c|c|c|c|}
\hline \multirow[b]{2}{*}{ Anos } & \multicolumn{2}{|c|}{ Metas alcançadas nas } & \multirow{2}{*}{$\frac{\text { präticas }}{\text { Adubação }}$} & \multirow{2}{*}{$\begin{array}{c}\text { e comendadas } \\
\text { Calagem }\end{array}$} & \multirow{2}{*}{$\begin{array}{l}\text { s pela CEPL } \\
\begin{array}{l}\text { Raleamento } \\
\text { de sombra }\end{array}\end{array}$} & \multirow[b]{2}{*}{ Poda } \\
\hline & $\begin{array}{c}\text { Combate } \\
\text { as pragas } \\
\end{array}$ & $\begin{array}{c}\text { Controle } \\
\text { de doenças }\end{array}$ & & & & \\
\hline 1965 & 22.000 & --- & 196 & --- & --- & --- \\
\hline 1966 & 41.000 & --- & 1.320 & $-\cdots$ & --- & 150 \\
\hline 1967 & 75.000 & 11.720 & 2.356 & --- & 2.321 & 2.241 \\
\hline 1968 & 80.800 & 3.305 & 2.887 & $-\cdots$ & 1.728 & 3.259 \\
\hline 1969 & 86.000 & 4.888 & 22.769 & --- & 4.872 & 4.032 \\
\hline 1970 & 125.000 & 6.136 & 72.000 & 11.980 & 21.456 & 5.561 \\
\hline 1971 & 104.860 & 12.605 & 85.010 & 9.568 & 25.382 & 8.300 \\
\hline 1972 & 124.116 & 8.800 & 96.120 & 9.807 & 27.357 & 12.581 \\
\hline 1973 & 155.114 & 13.998 & 133.679 & 14.455 & 33.026 & 19.902 \\
\hline 1974 & 157.780 & 19.890 & 114.766 & 8.709 & 41.945 & 31.956 \\
\hline 1975 & 169.800 & 26.176 & 97.100 & 7.948 & 21.555 & 44.889 \\
\hline 1976 & 189.012 & 34.400 & 96.056 & 11.205 & 23.956 & 59.178 \\
\hline 1977 & 323.400 & 76.500 & 149.700 & 17.100 & 37.700 & 79.628 \\
\hline 1978 & 295.545 & 110.802 & 165.807 & 15.401 & 37.407 & --- \\
\hline 1979 & 382.794 & 124.498 & 213.131 & 22.016 & 39.677 & -- \\
\hline
\end{tabular}

FONTE: Departamento de Extensão da CEPLAC

Em 1964 a ärea cultivada com cacaueiros em pro dução no Estado da Bahia foi estimada em 400.000 hectares, e 
destes, aproximadamente $60 \%$, ou seja 240.000 hectares, encon trava-se com idade superior a 40 anos e em estado de decadência, CEPLAC (1971).

A medida que uma lavoura de cacau se torna decadente, verifica-se uma perda de homogeneidade da plantação com o desaparecimento de ärvores péla morte natural ou aciden tal, pelo ataque de pragas ou doenças, por estiagens prolon gadas, por falta de replantio ou mesmo por mau aproveitamento de brotos das plantas tombadas, implicando no mau aproveita mento dos solos, GARC!A (1974).

A longo prazo, para continuar com uma cultura economicamente viável, haveria a necessidade de renovar os ve Ihos cacauais, principalmente pelo fato de estarem instalados nos melhores solos para cacau, e concentrados em äreas que contam com facilidades de infra-estrutura e disponibilidade de recursos humanos.

Em 1965, a Comissão Executiva do Plano da Lavou ra Cacaueira (CEPLAC) instituiu um programa de renovação de ca caueiros, visando a recuperação das áreas em decadéncia atravēs da substituição dessas plantações por outras de maior potencial produtivo desenvolvidas pelas pesquisas genéticas rea l izadas no CEPEC.

Apesar dos esforços dedicados a esse programa, os resultados alcançados ficaram aquém das necessidades de re novação, que atingiu uma ärea aproximada de 9.000 hectares ao 
final de 1975. Os baixos resultados alcançados nesse período são atribuídos à inexistência de material botânico em quantidade suficiente que pudesse atender ao programa, além do dese jo dos agricultores de continuar colhendo cacau nas áreas decadentes, passíveis de renovação.

Posteriormente, em 1976, a CEPLAC propos o PRO CACAU (Programa Nacional de Expansão da Cacauicultura), cujo principal objetivo é garantir ao Brasil o primeiro lugar na produção mundial de cacau, prevendo atingir em 15 anos uma pro dução anual de 700.000 toneladas de cacau.

Uma das metas a atingir para a consecução dos objetivos propostos no PROCACAU é a renovação de 150.000 hectares de cacau, num prazo de dez anos, a partir de 1976.

Atualmente a CEPLAC recomenda dois métodos de renovação de cacaueiros: 0 método de renovação sob lavouras decadentes, que consiste no aproveitamento dos cacaueiros decadentes como sombra provisöria aos novos cacaueiros até a fa se do início da produção comercial, quando aqueles são defin tivamente erradicados, e, o método de derruba total, que consiste na erradicação total dos cacaueiros decadentes, proceden do-se posteriormente ao plantio dos novos cacaueiros. Este método é sempre usado quando as äreas de cacaueiros decadentes não apresentam certas condições técnicas, que recomendam o uso do primeiro método, FERREIRA (1977). 
Dos 150.000 hectares de cacau a serem renovados 90.000 hectares serão pelo "método sob lavouras decadentes" e o restante pelo "mētodo de derruba total".

Analisando-se o desenvolvimento do programa de renovação de cacauais proposto pelo PRoCACAU (Programa Nacional de Expansão da Cacauicultura) verifica-se uma defasagem a nual entre as metas programadas e executadas. Em termos de va lores acumulados, observa-se que no final do quinto ano de vi gência do programa foram alcançadas somente $51,69 \%$ das metas programadas para o Estado da Bahia naquele período (Quadro 4).

QUADRO 4 - Metas programadas e alcançadas, em hectares, pelo programa de renovação de cacauais do Estado da Ba hia no Período de 1976/80. (Valores anuais e acu mulados)

\begin{tabular}{cccccc}
\hline Anos & Valores Anuais & Valores acumulados \\
\cline { 2 - 5 } & $\begin{array}{c}\text { Programado } \\
\text { ha }\end{array}$ & $\begin{array}{c}\text { Alcançado } \\
\text { ha }\end{array}$ & $\begin{array}{c}\text { Programado } \\
\text { ha }\end{array}$ & $\begin{array}{c}\text { Alcançado } \\
\text { ha }\end{array}$ \\
\hline 1976 & 5.000 & 751 & 5.000 & 751 \\
1977 & 5.000 & 3.362 & 10.000 & 4.113 \\
1978 & 10.000 & 4.861 & 20.000 & 8.974 \\
1979 & 10.000 & 5.497 & 30.000 & 14.471 \\
1980 & 15.000 & 8.788 & 45.000 & 23.259 \\
\hline
\end{tabular}

FONTE: Departamento de Extensão da CEPLAC 
Admite-se que o lento desempenho do programa de renovação verificado nos ültimos cinco anos esteja relacionado com a elevação do preço de cacau que permitiu um maior uso de tecnologias do tipo químico-biológico, elevando o rendimen to de äreas que anterioremente eram antieconômicas, levando os agricultores a adiarem o programa de renovação dessas àreas de cadentes.

Acredita-se também, que os altos custos da renovação e o retardamento do fluxo de renda durante o período de desenvolvimento das novas plantas, constituem as principais barreiras para os projetos de investimento em renovação de ca caueiros no Estado da Bahia.

Alēm disso sabe-se que embora o "método de renovação sob lavouras decadentes" apresente fluxos de caixa com valores negativos durante a fase de desenvolvimento das novas plantas, esses valores são menores do que os apresentados pelo "método de renovação com derruba total", devido ao fato de que com aquele método continua-se colhendo cacau das plantas de cadentes que permanecem na ārea durante o período inicial do processo de renovação.

Neste sentido estar-se-ia pressupondo que existem diferenças nas taxas internas de retorno dos projetos de investimento em renovação de cacauais no sul da Bahia, e que estas diferenças estejam associadas ao nível inicial de 
investimento requerido por cada processo de renovação, à perda de receitas decorrentes da erradicação dos cacaueiros deca dentes e ao nível de produtividade obtida com o plantio de sementes melhoradas.

\section{2 - OBJetivos do Estudo}

A determinação de causas econômico sociais que estão por trās da defasagem nas metas programadas se faz necessārio, envolvendo anālises que disponham de instrumentos ca pazes de mensurar a rentabilidade desses projetos.

Especificamente pretende-se:

a - Estimar o valor presente do fluxo de renda esperado por unidade de àrea ao longo do tempo, para cada processo de renovação em estudo;

b - Determinar as taxas internas de retorno por unidade de á rea, em diferentes äreas de cada processo de renovação;

c - Comparar as taxas internas de retornos obtidas em diferen tes āreas de um mesmo processo e entre os dois processos de renovação;

d - Comparar as taxas internas de retornos obtidas em diferentes äreas dos dois processos de renovação com a taxa interna de retorno aos investimentos agrícolas realiza dos no Brasil; 
12.

e - Selecionar a melhor alternativa de investimento em renovação de cacauais, sob o ponto de vista econômico, atravès da taxa "fisheriana" de investimento. 


\section{2 - REVISÃO DE LITERATURA}

As informações disponíveis na literatura a res peito de investimentos em atividades agrícolas perenes ainda säo escassas. De modo geral os trabalhos existentes sobre avaliação económica de investimentos realizados na agricultura, estão direcionados para a anälise de retornos e custos sociais ao capital investido nos programas de pesquisa e assistência tëcnica.

Nesta revisão considera-se os estudos que se preocuparam em medir os retornos aos investimentos realizados em cultivos perenes no Brasil, tanto do ponto de vista "publi co" como "privado".

MENEZES (1974), realizou um estudo de caso para avaliar os benefícios. resultantes de investimentos em reno vação de cacauais pelo método de derruba total no Estado da 
Bahia. Verificou que apesar da renda obtida da ārea ter supe rado os custos durante o período de maturação do investimento, esses benefícios foram menores do que a perda de renda que po deria ser gerada pelo cacaual decadente eliminado, e que isso refletia uma condição momentânea em que sé comparava cacaual decadente com cacaual novo em valorização crescente.

MONTEIRO (1975), avaliou os resultados econômi co dos ganhos sociais resultantes dos recursos aplicados em pesquisa e extensão agrícola em cacau no Brasil. 0 benefí cio bruto para a sociedade foi analisado tomando por base - deslocamento da curva de oferta para a direita, resultante do uso de tēcnicas modernas de cultivo produzidas pela pesqui sa e transferidas aos agricultores pelo serviço de extensão. Para estimar tais benefícios Monteiro considerou as situações de uma demanda internacional elástica e perfeitamente elásti ca para o cacau brasileiro. A estimativa da taxa interna de retorno variou de 16 a $20 \%$ para o período de $1923 / 85$ e de 61 a $79 \%$ para o período de $1958 / 85$.

FONSECA (1976), analisou os custos estimados e os retornos aos investimentos feitos em pesquisa e assistência tēcnica à cafeicultura no Estado de São Paulo. Quando se considerou apenas os gastos com pesquisa a taxa interna de re torno variou de $23 \%$ a $27 \%$ e quando considerou conjuntamente pesquisa e assistência tēcnica as taxas oscilaram de $17 \%$ a $22 \%$, 
em função da elasticidade - preço da oferta e da demanda. A au tora verificou que as taxas internas de retorno se mostraram mais sensíveis às variações na elasticidade preço da oferta do que às de demanda. Argumentou que o consumidor externo não se beneficiou muito do aumento da produtividade do café, decor rente de inovações produzidas pela pesquisa, devido ao fato do Brasil ter mantido os preços em níveis superiores aos prevale centes em condições de mercado livre.

TAFAN (1976), utilizou dados de corte trans versal como aproximação de sēries temporais para avaliar a economicidade da introdução de novas tecnologias na cultura do cacau no Brasil, levando em consideração a importância relat i va da idade das plantas nos diferentes lotes e fazendas. A análise realizada revelou que à variabilidade da produção por unidade de área está ligada a idade da planta, bem como à rea lização das práticas de raleamento de sombra e adubação. Me diante a técnica do valor presente, determinou as rendas líquidas excedentes ao longo da vida da planta, usando taxas de desconto entre $1 \%$ e $50 \%$. Nas condições de uso de tecnologia média (com raleamento de sombra e adubação), a taxa máxima de remuneração para as despesas de implantação e manutenção de um hectare de cacau foi de $30 \%$ com preço alto, e $15 \%$ com preço mé dio, enquanto nas condições de uso de tecnologia tradicional (sem raleamento de sombra e adubação), essas taxas foram de $35 \%$, $19 \%$ e $2 \%$ para os casos de preços alto, médio e baixo, respectivamente. 
As relações benefício/custo das tecnologias média e tradicional indicaram que esta ültima tecnologia é mais vantajosa do que a utilização de insumos modernos. Os resultados indicaram que as recuperações dos índices de produtividade, pela aplicação de insumos modernos, não foram suficientes para justificar a aplicação indiscriminada dessa tecnologia.

o estudo realizado por Tafani mostrou que a $\underline{i}$ dade de substituição das plantações velhas variou segundo a taxa exigida de remuneração do capital, e que a magnitude de $\underline{s}$ sa taxa exigida dependeria do nível de preço do produto e da tecnologia utilizada.

FERREIRA (1977), determinou o valor presente da renda cessante para diferentes tamanhos de àreas destinadas à renovação de cacaueiros pelo "método de derruba total", uti lizando dados da Fazenda Unitäria do CEPEC. Considerou a renda líquida média como base para a determinação do fluxo de renda cessante decorrente dos värios tamanhos de āreas destinadas a renovação. A renda cessante foi definida como a ren da líquida perdida durante o período de maturação do investimento, resultante do corte do cacaual decadente na fase ini cial do processo de renovação. Utilizou taxas de desconto en tre $18 \%$ e $30 \%$ para calcular o valor atual do fluxo de renda cessante nas condições de diferentes tamanhos de äreas destinadas a renovação. Calculou a relação renda-risco e verifi 
cou que o valor atual dos acréscimos da renda líquida mantém uma relação inversa com o tamanho de ärea destinada à renovação. Os resultados obtidos mostraram que a estratégia de usar novos processos produtivos em áreas de cacaueiros não de cadentes podem gerar acréscimo de renda cápaz de anular o efeito da renda cessante na renovação de cacauais.

MORICOCHI (1980), utilizou a concepção margina lista para estimar o retorno social aos investimentos realiza dos em pesquisa e assistência técnịca à citricultura no Estado de São Paulo. Para calcular os retornos foram utilizados valores de elasticidades já estimados e disponíveis na litera tura. A taxa interna de retorno variou de $18,33 \%$ a $27,61 \%$ ao ano, indicando que a pesquisa em citrus constitui uma exce lente opção de investimento para o Estado de São Paulo (29).

MATSUNAGA (1981), avaliou os retornos de inves timentos realizados no sistema moderno de produção de café com diferentes tecnologias e com alternativas de plantio de cultu ras intercalares, com o objetivo de comparar a tecnologia recomendada pelos örgãos de extensão, com a alternativa tecnoló gica que poderia viabilizar pequenos e médios produtores, da da a restrição do fator terra por eles enfrentada.

A análise efetuada através do critério da taxa interna de retorno para as diferentes alternativas, mostrou 
vantagem para o sistema moderno de cultivo de café, com tecnolo gia mecânica, apesar de apresentar menor taxa interna de retorno que as principais alternativas do café adensado. 0 sís tema moderno tecnologia mecânica apresentou resultados superiores aos demais sistemas, principalmente quando se utilizou o feijão como cultura intercalar. 0 valor atual desse sís tema, calculado a taxa de desconto de $6 \%$ a.a., ultrapassou os valores atuais dos demais sistemas, situando-se em torno de 23 milhões de cruzeiros. Os resultados comprovaram que este sistema de plantio foi mais apropriado para as grandes pro priedades. A comparação da alternativa erradiação de $50 \%$ no sistema de café adensada com o grupo de tecnologia manual e tecnologia com tração animal no sistema moderno, revelou ser a primeira melhor, pois apresentou valor atual superior as ou tras duas tecnologias utilizadas. Além disso, o café adensado viabilizou economicamente pequenos e médios produtores e evitou a concentração dos benefícios da política para os gran des produtores. 
19.

\section{3 - METODOLOGIA}

\section{1 - A Técnica da Fazenda Unitária}

Na conceituação de JOLLY (1957) a fazenda unitária é aquela criada e controlada por um economista agrícola para servir como um laboratório de experimentação em administra ção rural. Está desenhada para permitir ao investigador exer cer completo controle sobre a fazenda na qual se conduz o experimento, tanto do ponto de vista de técnicas agronômicas, co mo a organização da mão-de-obra, do capital de investimento, combinação de atividades, intensidade de aplicação de recursos e outros.

Segundo ÁLVARES AFONSO (1967) à fazenda unitária

é de natureza experimental e essencialmente dinâmica. A experimentação que nela se faz é de natureza econômica e não se de ve realizar experimento de caráter agronômico. Uma investiga 
ção com a fazenda unitāria somente deve ser iniciada no caso de existir uma raozável acumulação de conhecimentos agronômicos disponíveis para pronta utilização pela unidade.

\title{
3.2 - A Fazenda UnitáRIA do CEPEC
}

\begin{abstract}
ALVARES AFONSO (1969), implantou um projeto de pesquisa na ärea do Centro de Pesquisa do Cacau (CEPEC), com a finalidade de estudar dois métodos de renovação de cacauais a través da tēcnica da fazenda unitária. Esse projeto de pesquisa ocupa uma área aproximada de quarenta e cinco he $\underline{c}$ tares e passou a ser conhecido como Fazenda Unitária do CEPEC, ( Figura 1).
\end{abstract}

A Fazenda Unitária do CEPEC foi dividida em duas partes aproximadamente iguais, sendo uma delas denominada Fazenda Sempre Viva que tem como finalidade o estudo da re novação de cacauais pelo "método de derruba total", e a outra denominada Fazenda Moroziana que se dedica ao estudo da renovação pelo "método sob cacaueiros decadentes". Cada uma dessas partes foi subdividida em onze blocos de dois hectares, excetuando-se o ültimo bloco da Fazenda Sempre Viva que tem dois e meio hectares e da Fazenda Moroziana que tem três hectares. Esta subdivisão tem o objetivo de facilitar o trabaIho de observação, controle de produção e contabilidade, que neste caso è setorial, alēm de permitir uma anālise detalhada 


\section{LEVANTAMENTO DETALHADO DOS SOLOS DA AREA DO CEPEC 1968}

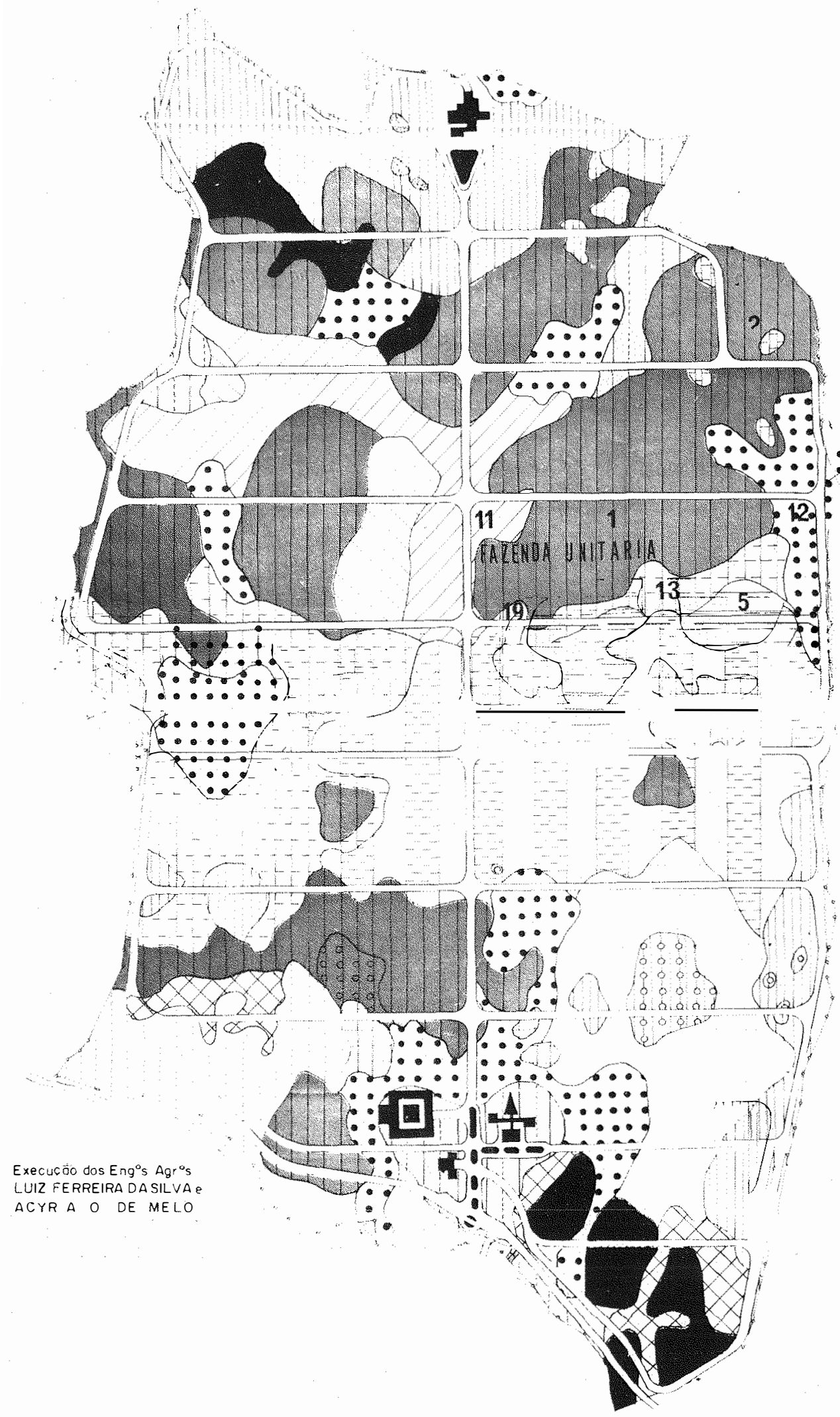

UNIDADES CARTOGRAFICAS

I SERE RTOUÇÃO

2 SÉRIE PRO UÇĀO fose pedregosa

3 SE'RIE BANANAL

4 SÉrie sāo MIGUEL

5 SERIE germoplasma

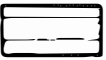

6 SÉRIE BENGO

7 SÉRIE SÉDE

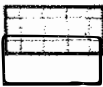

8 SÉRIE SÉDE fose pedregoso

9 SĖRIE SÉDE fase declivosa

10 série ribeirso das alegrias

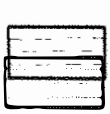

I SÉRIE RIBEIRĀO DOS PINTOS

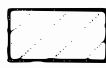

12SÉRIE PINTADA

I3SÉrie VIVEIRO
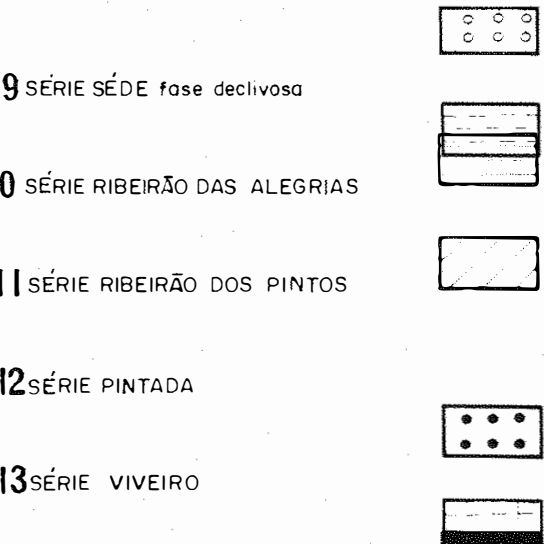

14 sétie Grituivia

I5 SÉRIE CORUMBÁ

16 SÉrie terraço

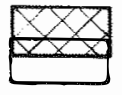

17 SÉRIE LITÓLICA

I 8 SÉRIE COVOADO

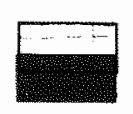

19 comple xo. de solos "GleI"

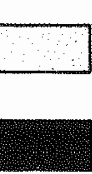


dos fatores que afetam a produtividade, o que permite estabelecer com antecipação uma prioridade de renovação dos blocos. No primeiro ano de atividade na Fazenda Unitāria procedeu-se o levantamento do nümero de cacaueiros e ärvo res de sombra por bloco e calculou-se a margem bruta anual para facilitar a escolha dos blocos a serem renovados. Assim, antes de iniciar a renovação dos blocos que no final do ano a presentassem as margens brutas de menor magnitude era feito um julgamento de campo para identificar os fatores responsāveis pela baixa produtividade.

Para apurar, os resultados, não sō da fazenda, mas de cada um dos seus blocos adotou-se um sistema de conta bilidade. Dessa forma seria possível identificar os blocos de menor rendimento e os problemas responsāveis pelo baixo ren dimento desses blocos.

A Fazenda Unitāria estā localizada numa região cujos cacaueiros encontram-se com idade bastante avançada, e possui características de solo e tamanho bem semelhante às fa zendas encontradas nessa região. Embora essas características permitam admitir que a Fazenda Unitäria representa uma fazenda típica da região onde està instalada, alguns problemas tais como o seu sistema de administração e contabilidade a diferen cia bastante das outras fazendas encontradas na região. 


\title{
3.3 - Consideracões Teóricas sobre Investimento em Renova-r gão dE CACAU
}

\author{
A inversão de capital em renovação de cacauais \\ decadentes pode ser considerada como um projeto de investimen \\ to, devido a natureza perene do cacau. Presume-se que o ca- \\ cauicultor tem como objetivo maximizar o valor presente descon \\ tado da corrente futura de receitas líquidas, derivadas de ín \\ versões realizadas em renovação do cultivo. \\ 0 comportamento dos fluxos descontados de re - \\ ceitabruta $R(t) e^{-r t}$ e decustos $C(t) e^{-r t}$, duranteotem \\ po $t$ a uma taxa de desconto $\underline{r}$, pode mostrar através do tempo \\ que os cacauicultores enfrentam dois períodos em que a ativi- \\ dade resulta não econômica, como consequência de serem os mon \\ tantes de receitas insuficientes para cobrir os custos de re- \\ novação e manutenção do cultivo, TAFANI (1976). \\ Desta forma, existiriam dois pontos no tempo, \\ um $t$ (e) que indicaria o momento em que o cultivo começaria a \\ dar receita liquida positiva e outro $t(a)$ em que a corrente \\ de custos descontados começaria a ser maior do que, a corrente de \\ receita bruta descontada (Figura 2).
}




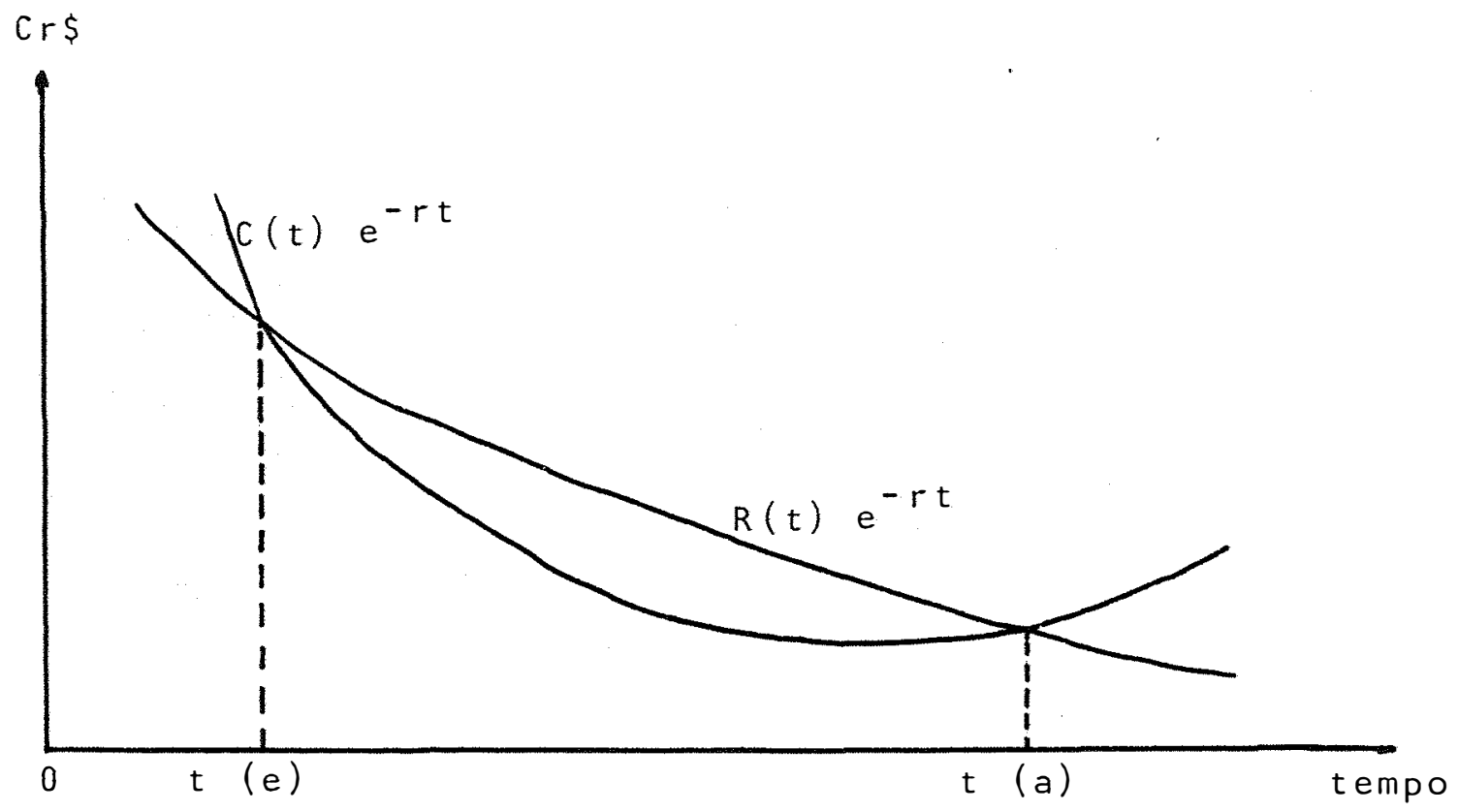

FIGURA 2 - Comportamento hipotético de fluxos descontados de receita bruta e custos no tempo.

Implicitamente deve-se considerar um determina do preço do produto e dos insumos no mercado, pois a variação dos mesmos poderia mudar o ponto $t$ (a) no tempo.

Quando se alcança o ponto $t$ (a), como consequência da baixa produtividade por unidade de ärea do cultivo devido a idade avançada das plantações, deve-se realizar a substituição dos cacaueiros velhos por variedades novas, a fim de poder continuar com a atividade produtiva. 
A substituição de plantações decadentes pớr ou tras de maior rendimento físico por unidade de área, merece $\underline{u}$ ma análise detalhada entre os benefícios alcançados pelas novas plantações ao longo do tempo, e os esforços dispensados pa ra obtenção de tais benefícios. Para tantó deve-se considerar:

$B_{n}^{t} \equiv V P_{n}^{t}$, benefício das novas plantações no tempo $\underline{t}$, iqual ao valor presente do fluxo de receita bruta das novas plantações no tempo $\underline{t}$

$B_{V}^{t} \equiv V P_{V}^{t}$, benefício. líquido das velhas plantações no tempo $\underline{t}$, igual ao valor presente do fluxo de recei ta liquida das velhas plantações no tempo $\underline{t}$. $c_{n}^{t} \equiv$, custos de implantação e manutenção das novas plantações no tempo $\underline{t}$.

$S_{V}^{t} \equiv$, custos de erradicação ou remoção das plantações decadentes no tempo $\underline{t}$.

o valor presente líquido (V P N) do processo de renovação ao longo do tempo, serä igual aos benefícios menos os custos, ou seja:

$$
V P N_{n}=\left(B_{n}^{t}-B_{v}^{t}\right)-\left\{C_{n}^{t}-\left(-S_{v}^{t}\right)\right\},
$$

$\log 0$

$$
\begin{aligned}
& V P N_{n}=B_{n}^{t}-B_{v}^{t}-C_{n}^{t}+\left(-s_{v}^{t}\right) \quad \text { o que implica em } \\
& V P N_{n}=B_{n}^{t}-B_{v}^{t}-C_{n}^{t}-s_{v}^{t} .
\end{aligned}
$$


Quando a diferença for maior que zero, pode-se realizar a substituição de cacaueiros decadentes por novas plan tações e dizer que a renovação resulta economicamente viável se:

$$
V P N_{n}>0
$$

ou

$$
B_{n}^{t}>B_{v}^{t}+C_{n}^{t}+S_{v}^{t}
$$

A corrente de custos resultantes da inversão em renovação de cacaueiros, está constituída pela receita líqui da que se deixa de receber com o corte das velhas plantações $\left(B_{V}^{t}\right)$, mais os custos de implantação e manutenção das novas plantações $\left(c_{n}^{t}\right)$ e mais os custos de erradicação dos cacaueiros velhos $\left(s_{v}^{t}\right)$.

o custo de oportunidade do capital investido de ve refletir a taxa real que renderia esse capital em seu melhor uso alternativo. Para isso deve-se considerar preços reais ob tidos pela produção, computar custos reais e descontar a corrente de receitas líquidas a uma determinada taxa real.

A anālise hipotética do fluxo de receita bruta e de custos durante o ciclo da cultura, quando se realiza a re novação de cacauais pelo método de derruba total, assume um comportamento esquemático como na Figura 3 . 0 valor atual da receita líquida da cultura, em valores corrigidos, seria dada pela diferença entre as áreas $A$ e $B$, caso a receita bruta e custos sejam considerados em tempo contínuo. 


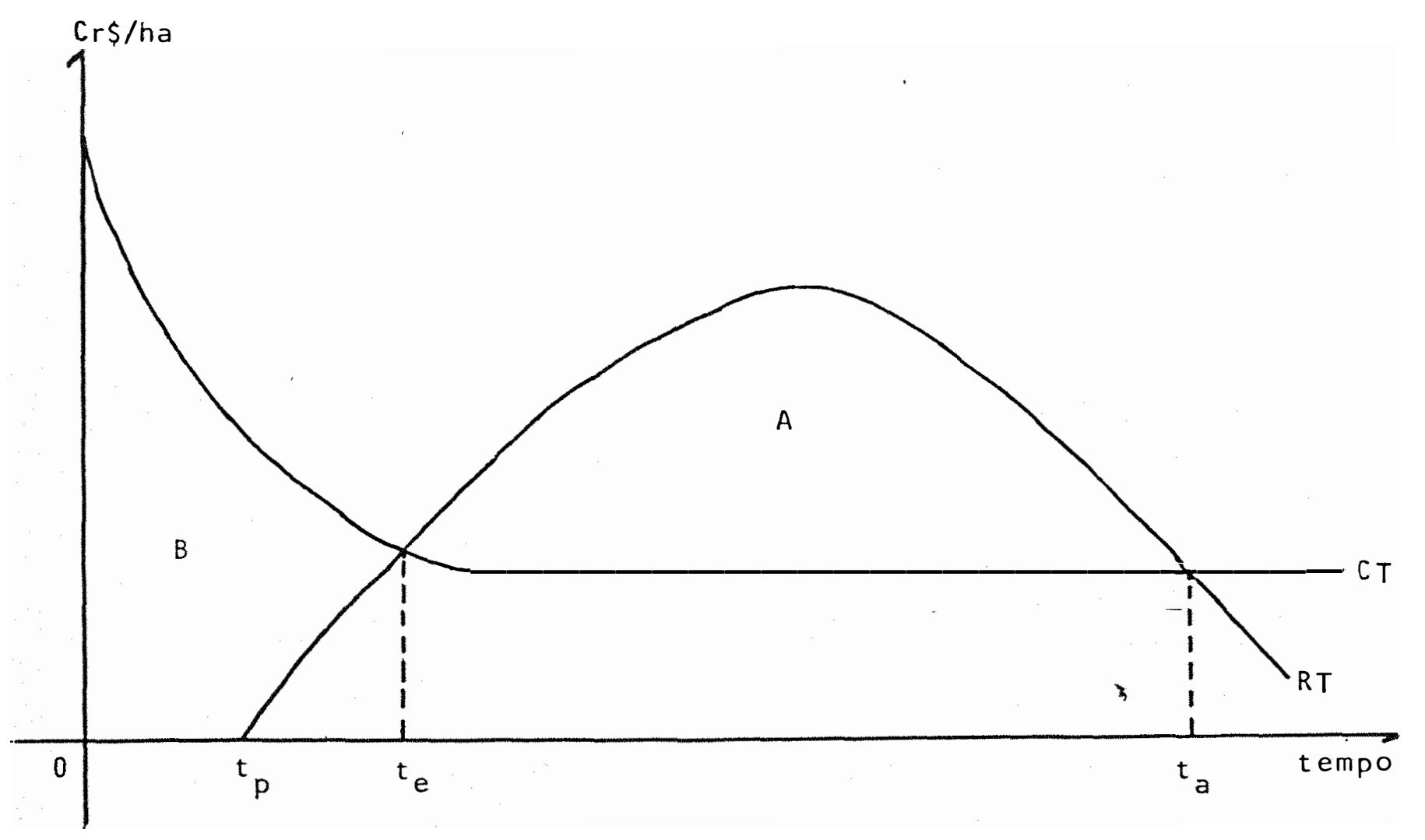

FIGURA 3 - Comportamento hipotético de receita bruta (RT) e custos de implantação e manutenção da cultura de cacau (CT), ao longo do tempo, para uma unidade de àrea,quando se usa o método de renovação com derruba to tal. 
Entre os momentos zero e $t_{e}$, as receitas líqui das seriam negativas, pois inicialmente há um período $t_{p}$ em que a produção é nula, e um período $t_{e}{ }^{-} t_{p}$ em que a produção é insuficiente para cobrir os custos de exploração. A re ceita líquida seria positiva entre os momentos te e $t_{a}$, e voltaria a ser negativa após o momento $\mathrm{t}_{\mathrm{a}}$, devido a queda da produtividade das ärvores, decorrente do avanço do seu ciclo biolögico. Supondo-se que os agricultores quisessem evitar as perdas posteriores a $t_{a}$, iniciariam um novo ciclo de renovação. A receita líquida total da cultura seria dada pela dife rença entre as äreas (A) - (B).

Quando se utiliza o método de renovação sob cá caueiros decadentes, verifica-se uma mudança no esquema de anälise hipotética do fluxo de receita bruta e de custos, conforme pode-se observar na Figura 4. Apesar da receita líquida, em valores reais, ser negativa entre os momentos zero e te, em termos absolutos essa receita é menor do que aquela obtida para o método de renovação com derruba total, pois con tinua-se colhendo cacau das plantas decadentes que permanecem na ärea durante a fase inicial do processo de renovação.

Entre os momentos zero $e t_{e}$ as receitas brutas obtidas dos cacaueiros decadentes que permanecem na ärea são insuficientes para cobrir os custos de produção e renovação.

A receita líquida seria positiva entre os momentos te e ta e voltaria a ser negativa após o momento ta, devido a queda de produtividade pelo avanço da idade das plantas. 


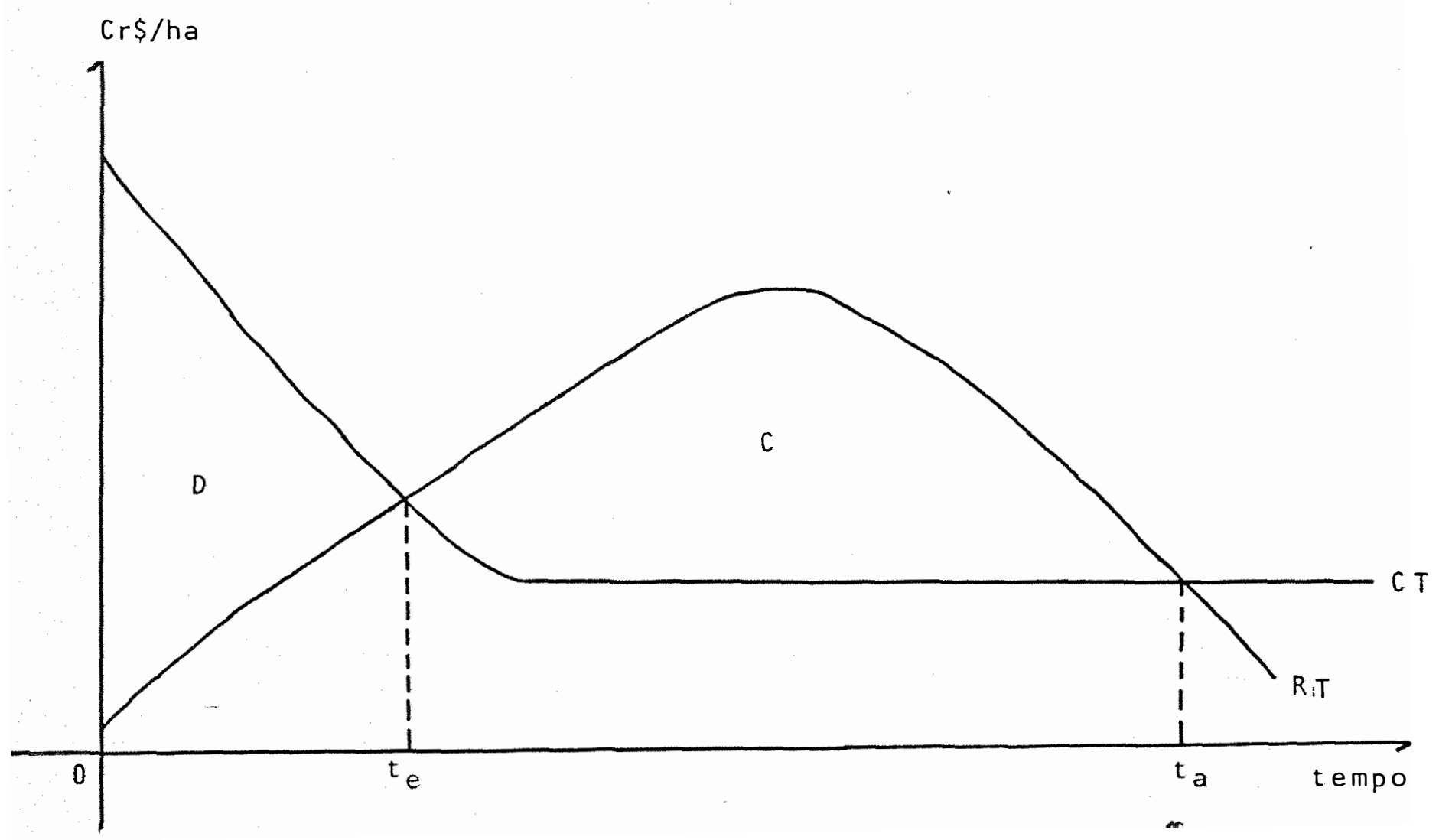

FIGURA 4 - Comportamento hipotético da receita bruta $(R T)$ e custos de implantação e manutenção da cultura do cacau ( $C T$ ), ao longo do tempo, para uma unidade de àrea, quando se usa o método de renovação sob cacaueiros re cadentes. 
A receita líquida total da cultura seria obtida pela diferença entre as āreas (C) - (D).

Quando se compara os dois métodos, parece

que a receita líquida total da cultura resulta maior para o método de renovação sob cacaueiros decadentes, pois a adoção desse método implica em continuar colhendo cacau das plantas decadentes que permanecem na ärea durante a fase inicial do processo de renovação, o que não ocorre com o método de renovação com derruba total.

\section{4 - Avaliagão de Investimentos em Renovagão de Cacau}

A inversão de capital em renovação de cacauais, pode ser caracterizada como um projeto convencional de investimento. Diante dessa abordagem, os insumos e produtos associados ao ciclo biológico da cultura devem ser quantificados em termos monetärios, para que se possa determinar os desem bolsos e receitas que ocorrerão ao longo do tempo.

Neste estudo admite-se que as receitas e custos ocorram após intervalos de tempo iguais e finitos, ou seja, to das as receitas e custos que ocorrerem durante um ano qualquer estarão concentradas no fim desse ano.

Assim, o projeto de investimento é caracteriza do por uma sequência de nümeros reais, $a_{j}, j=1,2, \ldots$, 
$n$, onde $a_{j}$, receita líquida relativa ao período $\underline{j}$, repre senta o fluxo de caixa associado ao projeto durante o j-ésimo periodo, concentrado no fim do intervalo de tempo ao qual se refere. Quando $a_{j}>0$, ao longo do período $\underline{j}$, teremos excesso de receita em relação aos custos, e quando $a_{j}<0$ te remos o inverso.

Dentro do horizonte de dados do projeto supõese que as estimativas do fluxo de caixa, a $a_{j}$, sejam eventos certos; ou seja estudar-se-ä apenas o caso dito determinístico.

Um projeto de investimento é caracterizado como convencional quando:

$$
\begin{aligned}
& a_{0}<0 \\
& a_{j} \leq 0 \text { para } j=1,2,3, \ldots, k \text {, m } \\
& a_{j}>0 \text { para } j=k+1, \ldots, n \text { e } \\
& j=\sum_{k+1}^{n} a_{j}>-\sum_{j}^{k} a_{j}
\end{aligned}
$$
quando apresenta uma só mudança de sinal na sequência de seus fluxos de caixa. Após um espaço de tempo em que os custos ex cedem ou igualam as receitas, verifica-se receitas superiores aos custos até o final do horizonte do projeto (FARo, 1971). Quando um projeto apresenta mais de uma variação de sinal na sequência do fluxo de caixa, è dito não-con - 
vencional, embora tenha que satisfazer as seguintes condições :

$$
\begin{aligned}
& a_{0}<0 \\
& j \stackrel{\sum_{0}}{=} a_{j}>0
\end{aligned}
$$

Para avaliar os resultados de investimentos rea l izados em renovação de cacauais considerar-se-ä somente os cri térios que levam em conta a variação que o capital sofre com o tempo .

\title{
3.4.1 - Critério do valor atual
}

\begin{abstract}
Considerando-se o regime de juros compostos ä taxa $i$, sob forma unitäria e relativa ao mesmo intếrvalo de tempo entre receitas consecutivas, o valor atual de um projeto é obtido da soma algëbrica dos valores descontados dos flü xos de caixa a ele associados.
\end{abstract}

$$
V=j \sum_{0}^{n} a_{j}(1+i)^{-j}
$$

A taxa de juros positiva reflete a preferència em receber Cr $\$ 100,00$ agora do que esse mesmo valor ao fim de um período, porque a inversão desse capital, a uma determinada taxa de juros, renderia ao fim do período Cr $\$ 100,00$ $(1+i)^{1}$. Isso significa que os Cr\$100,00 recebidos agora cor 
respondem ao valor atual ou descontado a uma determinada taxa de juros $i$.

$$
\text { Quando o valor atual de um projeto é positivo }
$$
significa que, para uma determinada taxa de desconto, o valor atribuído hoje às receitas líquidas futurás é superior ao investimento inicial necessário a sua implementação, indicando ser o projeto economicamente interessante em relação à taxa estipulada.

A escolha de um projeto segundo o critério do valor atual leva em consideração o maior valor atual líquido. o principal problema associado ao critério em questão, é o de se utilizar a taxa de desconto adequada na determinação do valor atual.

\section{4 .2 - CRITÉrio DA TAXA INTERNA DE RETORNo}

Por definição, a taxa interna de retorno de um projeto, é a taxa de desconto $\alpha$, real e não negativa, para a qual se verifica a relação:

$$
\begin{aligned}
& \sum_{j=0}^{n} a_{j}(1+\alpha)^{-j}=0 \\
& a_{0}+\sum_{j=1}^{n} a_{j}(1+\alpha)^{-j}=0
\end{aligned}
$$

ou

$$
-a_{0} \neq \sum_{j}^{n} a_{j}(1+\alpha)^{-j}
$$


ou seja, a taxa interna de retorno é a taxa de desconto que iguala o valor atribuído às receitas futuras ao cus to do investimento, isto é, a taxa que anula o valor atual lí quido do projeto, FARO (1971).

Para os casos de projetos simples e convencionais, esta taxa existirā sempre e serä ünica, enquanto nos ca sos de projetos não convencionais poderá ocorrer mais de uma taxa, real e não negativa, que anula o valor atual do projeto, o que resultará em mūltiplas taxas internas de retorno.

A taxa interna de retorno $\alpha$, raiz real e posi tiva da equação acima, representa a maior taxa de juros para a qual o projeto tem valor atual não negativo. Um projeto se rá tanto mais desejāvel quanto maior for a taxa interna de re torno. Um projeto será economi camente desejāvel, quando sua taxa interna de retorno for superior a uma dada taxa de juros, denominada taxa mínima de atratividade; quando a taxa interna de retorno for igual a taxa mínima de atratividade, o projeto é considerado marginal, e quando for menor do que a taxa mínima de atratividade, o projeto será inviável.

A limitação desse critério reside na definição da taxa relevante que deve ser utilizada para efeito de análi se. Esta taxa, denominada taxa minima de atratividade, deve representar, para cada caso em questão, o que se deixa de ga- 
nhar pela não aplicação do capital na melhor alternativa dispo nivel.

\subsection{3 - Limitações dOS CRITÉRIOS de AVALIAGÃo CITAdoS}

No caso de projetos de investimento do tiposim ples ou convencional que sejam compatíveis ou independentes en tre si, e não havendo restrição orçamentāria, os resultados da seleção segundo os dois critērios serão sempre consistentes. Para projetos convencionais, esses dois critérios de avaliação conduzirão ao mesmo resultado, pois se $\alpha^{\star}>i^{\star}$, onde $\underline{i}^{*}$ é a ta xa mínima de atratividade, o projeto apresentará um valor atual positivo quando calculado à taxa $i^{*}$.

Visto que no critērio do valor atual hä difi culdade de se determinar a taxa mínima de atratividade, o cri tério da taxa interna de retorno, que aparentemente independe daquela taxa, pois pode ser calculada tendo por base somente dados do projeto, deveria ser o mais apropriado. Entretanto, para que se possa decidir se um projeto é aceito ou não, deve-se comparar a taxa interna de retorno obtida com a taxa mí nima de atratividade, recaindo-se no problema apresentado pelo critério do valor atual (MATSUNAGA, 1981).

Quando hà necessidade de se comparar dois ou mais projetos de investimento que sejam mutuamente exclusivos, existe o fato de que nem sempre o projeto com maior taxa inter 
na de retorno seja o mais atrativo, sendo necessärio recorrer ao cälculo da taxa interna de retorno do investimento incre mental e comparar com a taxa alternativa.

Para selecionar projetos que sejam mutuamente exclusivos, deve-se determinar a taxa de retorno sobre os cus tos de FISHER. Esta é a taxa interna de retorno do projeto, cujos fluxos de caixa resultam da diferença entre os flü xos de caixa homölogos de dois projetos em anälise, feita para cada par de alternativas do conjunto (FARo, 1971).

Representando-se por a $a_{j}$ fluxo de caixa, na época $\underline{j}$, associado ao projeto $A$, e por $b_{j}$ o fluxo de caixa associado ao projeto B nessa mesma época $\underline{j}$, e supondo que os dois projetos tenham a mesma vida ūtil e possuam o mesmo hor zonte de planejamento, a taxa "fisheriana" relativa a compara ção entre os projetos A e B será a taxa representada por (B-A), que serä a solução real e não negativá da equação:

$$
\begin{aligned}
& \sum_{j=0}^{n}\left(b_{j}-a_{j}\right)(1+\alpha)^{-j}=0 \\
& \quad \text { Esse cálculo não requer dados sobre o custo de }
\end{aligned}
$$
oportunidade do capital, que representa o aspecto crítico do valor atual. A taxa interna de retorno apresenta os projetos viàveis, mas não permite selecionar a melhor alternativa,pois este critērio não considera as diferenças entre os gastos de investimento dos projetos que estão sendo cotejados. Também podem ocorrer casos de não se ter somente uma ünica taxa inter 
na de retorno, e sim múltiplas soluções para taxa interna.

Este critērio apresenta resultados consistentes quando os pro jetos são independentes, MATSUNAGA (1981).

Dentre os critērios mencionados, verifica-se

que nenhum deles é isento de limitação, entretanto existe um ponto em comum que é a taxa relevante determinada para efeito de anālise ou comparação.

Neste estudo, a avaliação do melhor método de renovação de cacauais será cotejado com base nos fluxos de cai xa descontados. Sob o ponto de vista econômico, a melhor alternativa de investimento é aquela que apresenta o maior valor atual líquido ou, alternativamente, a maior taxa interna de re torno, desde que esteja acima da taxa mínima tomada como refe rência para efeito de comparação.

A avaliação e seleção do melhor método de reno vação de cacauais far-se-à mediante o critērio do valor atual e da taxa interna de retorno.

\section{5 - Fonte dos Dados}

os dados utilizados foram obtidos a partir de relatörios anuais de resultados econômicos da Fazenda Unitá ria do CEPEC no período de 1969/70 a 1980/81. Utilizou se simulações baseadas em informações existentes na litera tura e nos coeficientes técnicos extraídos desses relatörios, a fim de obter uma aproximação de sēries temporais de produção 
e custos para cada unidade de ärea estudada.

A Fazenda Unitāria foi instalada em 1969/70.

Neste primeiro ano de atividade procedeu-se o levantamento do nümero de cacaueiros e ärvores de sombra e calculou-se a margem bruta anual para facilitar a escolha do bloco a ser renovado. Assim, antes de iniciar a renovação dos blocos que no final do ano apresentaram as margens brutas de menor magnitude, fez-se um julgamento em campo para verificar os fatores responsáveis pela baixa produtividade.

Com base nesses critērios, a prioridade de renovação através do método de derruba total recaiu sobre os blo cos um, seis e oito, e para o método de renovação sob cacaue ros decadentes selecionou-se os blocos três e sete. Portanto, os dados básicos e os coeficientes técnicos usados neste trabalho referem-se exclusivamente a esses blocos renovados.

A partir de um sistema contábil instalado na Fazenda Unitāria, com relatōrio diārio de todas atividades desen volvidas nos blocos, determinou-se o custo de tais atividades. Posteriormente estes valores foram utilizados para o preench mento do relatório mensal, e no final de cada ano agrícola pro cedeu-se a análise financeira privada de cada bloco individual mente. 


\section{4 - RESULTADOS E DISCUSSÃO}

Para avaliar os retornos aos investimentos rea lizados em renovação de cacauais na Fazenda Unitäria do CEPEC, adotou-se os critērios do valor atual e da taxa interna de retorno. Esses critērios foram utilizados com a finalidade de apresentar os projetos viāveis, pois a taxa interna por si sö pode levar a escolha errada se os projetos são mutuamente exclusivos.

Na comparação entre os dois métodos de renovação julgou-se necessärio calcular a taxa interna de retorno do investimento incremental e considerar o cälculo do valor atual, a fim de selecionar o mētodo de renovação mais desejável do ponto de vista econômico. Esses critērios levam em conta o volume inicial de investimento de cada projeto individualmente. 
Como o horizonte de dados existentes na Fazenda Unitäria corresponde a um período de apenas ll anos, utilizou-se coeficientes técnicos extraídos dos relatörios anuais da fazenda e informações disponíveis na literatura, a fim de ampliar o horizonte de planejamento e estimar, com razoável precisão, os futuros fluxos de caixa associados a cada alternativa estudada.

\section{1 - Produtividade e Ciclo de Produgão Considerado}

A cultura do cacau, sendo permanente, tem um período de formação de cinco a seis anos, a partir do qual a produção entra em escala comercial.

Estudo realizado por TAFANI (1976), utilizando dados de cortes transversais para simular sēries temporais, in dicou que a produção de cacau por hectare crescia a taxas pro gressivas entre os primeiros 4 - 8 anos de idade, desde a implantação da cultura. Continuaria crescendo a taxas decres centes até atingir o mäximo, quando as plantas alcançassem idade pröxima aos vinte anos. Daí, em diante, iniciar-se-ia um processo de paulatino decréscimo na produtividade, até terem as plantas $60-70$ anos de idade.

Regra geral, existe um consenso entre os tëcn! cos de que o ciclo de produção de cacau é crescente nos primeiros oito anos de idade da planta, posteriormente estabili- 
za-se até as plantas atingirem idade pröxima aos vinte anos, e daí em diante começa um processo de decréscimo continuado na Produtividade. 0 período produtivo se prolonga até mais de 40 anos, desde que tratos culturais, como adubação por exemplo, sejam feitos regularmente a cada ano agrícola. Entretanto, a medida que a produtividade cai a um nível de $20-30$ arrobas por unidade de ärea, admite-se que seja interessante iniciar um novo ciclo de renovação a fim de continuar com a atividade econômica.

Assim, procurando verificar se a menor vida üti l conduz a resultados interessantes, em cada situação estudada tentou-se simular um ciclo de produção para um hectare de cacau. Isto foi feito, tomando-se como produção dos primei ros onze anos de idade das plantas os rendimentos médios por hectare, obtidos em cada bloco renovado, a partir de dados existentes nos relatōrios anuais da Fazenda Unitäría.

Calculou-se a média dos rendimentos nos ültimos três anos e fixou-se a produtividade constante do décimo segundo até o vigésimo primeiro ano, para posteriormente ir subtraindo $10 \%$ desse volume de produção sobre cada valor anual resultante, até as plantas atingirem uma produtividade média anual de 20 - 30 arrobas por hectare. Dessa forma, o ciclo de produção ficou definido em 33 anos apenas (Quadros 5 e 6). 
Nos Quadros 9 a 13 verifica-se que os níveis de produtividades observados, em cada bloco, no ano anterior ao início do processo de renovação foi inferior ao nível de produtividade considerada como limite (20 a 30 arrobas) para ini ciar um novo ciclo de renovação. Isto implica em superestimar os custos decorrentes da perda de receita líquida e consequen temente levar a uma subestimativa das taxas internas de retor no no presente estudo de caso. 


$$
\begin{aligned}
\text { QUADRO } 5 \text { - } & \text { Produção de cacau esperada, em arrobas por hecta } \\
& \text { re, nos blocos renovados pelo "Método de Derruba } \\
& \text { Total", considerando-se a idade das plantas }
\end{aligned}
$$

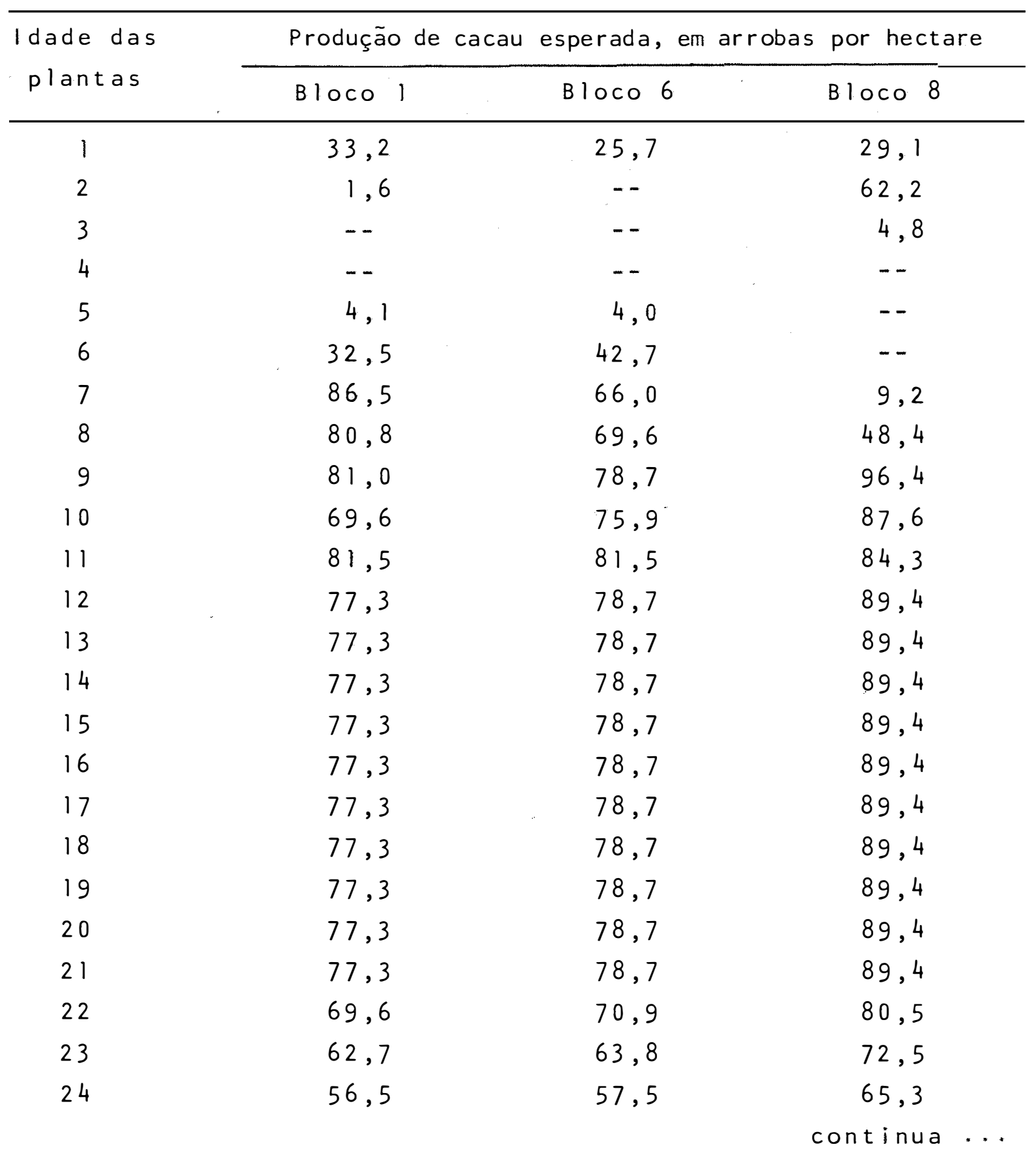


QUADRO 5 - Continuação

\begin{tabular}{cccc}
\hline \multirow{2}{*}{$\begin{array}{c}\text { dade das } \\
\text { plantas }\end{array}$} & \multicolumn{1}{c}{ Produção de cacau esperada, em arrobas por hectare } \\
\cline { 2 - 4 } 25 & Bloco 1 & B loco 6 & Bloco 8 \\
26 & 50,9 & 51,8 & 58,8 \\
27 & 45,8 & 46,6 & 52,9 \\
28 & 41,3 & 42,0 & 47,6 \\
29 & 37,2 & 37,8 & 42,9 \\
30 & 33,5 & 34,1 & 38,6 \\
31 & 30,2 & 30,7 & 34,8 \\
32 & 27,2 & 27,6 & 31,3 \\
33 & 24,5 & 24,9 & 28,2 \\
\hline
\end{tabular}




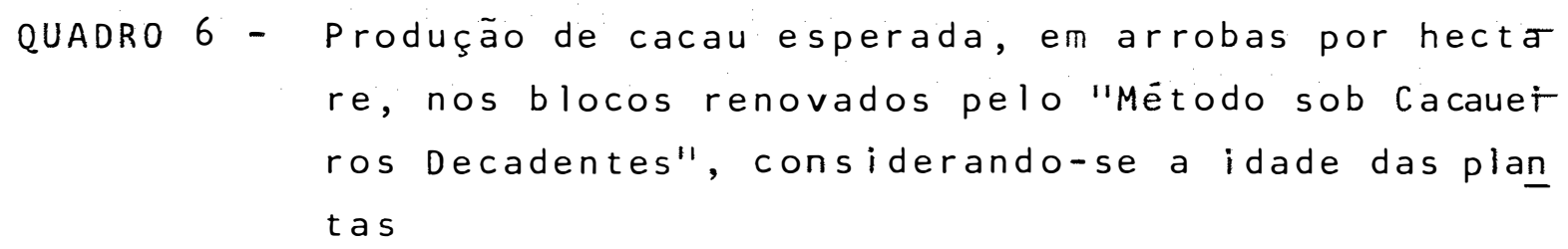
re, nos blocos renovados pelo "Método sob Cacauer ros Decadentes", considerando-se a idade das plan tas

\begin{tabular}{|c|c|c|}
\hline \multirow{2}{*}{$\begin{array}{c}\text { Idade das } \\
\text { plantas }\end{array}$} & \multicolumn{2}{|c|}{ Produção de cacau esperada, em arrobas por hectare } \\
\hline & B loco 3 & B loco 7 \\
\hline 1 & 47,9 & 45,4 \\
\hline 2 & 56,6 & 51,6 \\
\hline 3 & 23,1 & 26,4 \\
\hline 4 & 18,8 & 28,5 \\
\hline 5 & 17,6 & 2,7 \\
\hline 6 & 65,2 & 10,2 \\
\hline 7 & 125,0 & 38,2 \\
\hline 8 & 86,4 & 41,3 \\
\hline 9 & 105,5 & 74,0 \\
\hline 10 & 108,9 & 69,3 \\
\hline 11 & 82,2 & 51,6 \\
\hline 12 & 98,8 & 64,9 \\
\hline 13 & 98,8 & 64,9 \\
\hline 14 & 98,8 & 64,9 \\
\hline 15 & 98,8 & 64,9 \\
\hline 16 & 98,8 & 64,9 \\
\hline 17 & 98,8 & 64,9 \\
\hline 18 & 98,8 & 64,9 \\
\hline 19 & 98,8 & 64,9 \\
\hline 20 & 98,8 & 64,9 \\
\hline 21 & 98,8 & 64,9 \\
\hline 22 & 88,9 & 58,4 \\
\hline 23 & 80,0 & 52,6 \\
\hline & & cont inua \\
\hline
\end{tabular}




\begin{tabular}{lcc} 
QUADRO $6-$ & \\
\hline Idade das & Continua & \\
Plantas & Bloco 3 & B Ioco 7 \\
\hline 24 & 72,0 & 47,4 \\
25 & 64,8 & 42,7 \\
26 & 58,3 & 38,4 \\
27 & 52,5 & 34,6 \\
28 & 47,0 & 33,2 \\
29 & 42,3 & 29,9 \\
30 & 38,1 & 27,0 \\
31 & 34,3 & 24,3 \\
32 & 30,9 & 21,9 \\
33 & 27,8 & 19,7 \\
\hline
\end{tabular}




\section{2 - Estimativa da Receita Bruta por Hectare}

Multiplicando-se o preço médio anual recebido pelos agricultores pela produção física anual obtida para cada idade das plantas, determinou-se as receitas brutas por hec tare.

Os preços médios anuais recebidos pelos agricultores nos primeiros onze anos foram obtidos dos relatórios anuais da Fazenda Unitäria. 0 s preços de cada ano foram deflacionados, utilizando-se o rndice Geral de Preços da Fundação Getülio Vargas, ano base $1980=100$ (Anexo 1 ).

Nos primeiros onze anos do ciclo de vida da cul tura, o valor real da produção de cacau foi estimado levandose em consideração os preços observados nesse período. Como não se pode prever os preços que irão ocorrer no futuro, para calcular as receitas brutas posteriores a esse período, optouse por determinar um preço médio para ser utilizado na estima tiva das receitas futuras, com base nos preços observados nos últimos cinco anos.

Tendo-se como referência o problema discutido a cima obteve-se um preço médio aproximado de Cr\$2.100,00 por arroba de cacau seco. Esse critério é bastante razoável,pois os preços atuais do cacau situam-se em torno desse valor obti do. 
Tal computo de preços admite implicitamente que a qualquer momento que se faça a renovação, o ciclo de preços dos primeiros onze anos será semelhante ao observado, contudo só é välido para o,presente estudo de caso.

Assim, estimou-se as receitás brutas posteriores aos primeiros onze anos do ciclo da cultura, tomando-se como referéncia um preço médio fixado em Cr\$2.100,00 e cada um dos volumes de produção física por hectare, estimada para cada idade das plantas nos blocos renovados conforme o método utilizado (Quadros 7 e 8). 
QUADRO 7 - Receita bruta estimada, em cruzeiros por hectare, nos blocos renovados pelo "Método de Derruba Total", considerando-se a idade das plantas

\begin{tabular}{|c|c|c|c|}
\hline \multirow{2}{*}{$\begin{array}{l}\text { Idade das } \\
\text { Plantas }\end{array}$} & \multicolumn{2}{|c|}{ Receita bruta estimada em } & Cr\$ / ha \\
\hline & Bloco 1 & B $10 \mathrm{co} 2$ & Bloco 8 \\
\hline 1 & $20.338,32$ & $15.743,82$ & $17.826,66$ \\
\hline 2 & 695,72 & --- & $27.046,42$ \\
\hline 3 & --- & --- & $2.664,91$ \\
\hline 4 & --- & --- & -- \\
\hline 5 & $5.687,11$ & $5.548,40$ & --- \\
\hline 6 & $32.147,05$ & $42.236,27$ & --- \\
\hline 7 & $190.101,05$ & $145,048,20$ & $20.218,84$ \\
\hline 8 & $232.566,64$ & $200.329,68$ & $139.309,72$ \\
\hline 9 & $194.648,67$ & $189.212,61$ & $231.655,95$ \\
\hline 10 & $121.681,68$ & $132.695,97$ & $153.151,08$ \\
\hline 11 & $102.862,78$ & $102.862,78$ & $106.396,72$ \\
\hline 12 & $162.330,00$ & $165.270,00$ & $187.740,00$ \\
\hline 13 & $162.330,00$ & $165.270,00$ & $187.740,00$ \\
\hline 14 & $162.330,00$ & $165.270,00$ & $187.740,00$ \\
\hline 15 & $162.330,00$ & $165.270,00$ & $187.740,00$ \\
\hline 16 & $162.330,00$ & $165.270,00$ & $187.740,00$ \\
\hline 17 & $162.330,00$ & $165.270,00$ & $187.740,00$ \\
\hline 18 & $162.330,00$ & $165.270,00$ & $187.740,00$ \\
\hline 19 & $162.330,00$ & $165.270,00$ & $187.740,00$ \\
\hline 20 & $162.330,00$ & $165.270,00$ & $187.740,00$ \\
\hline 21 & $162.330,00$ & $165.270,00$ & $187.740,00$ \\
\hline 22 & $146.160,00$ & $148.890,00$ & $169.050,00$ \\
\hline 23 & $131.670,00$ & $133.980,00$ & $152.250,00$ \\
\hline
\end{tabular}


QUADRo 7 - Continuação

\begin{tabular}{|c|c|c|c|}
\hline \multirow{2}{*}{$\begin{array}{l}\text { Idade das } \\
\text { Plantas }\end{array}$} & \multicolumn{2}{|c|}{ Receita bruta estimada en } & Crs/ha \\
\hline & B. 10001 & Bloco 2 & Bloco 8 \\
\hline 24 & $118.650,00$ & $120.750,00$ & $137.130,00$ \\
\hline 25 & $106.890,00$ & $108.780,00$ & $123.480,00$ \\
\hline 26 & $96.180,00$ & $97.860,00$ & $111.090,00$ \\
\hline 27 & $86.730,00$ & $88.200,00$ & $99.960,00$ \\
\hline 28 & $78.120,00$ & $79.380,00$ & $90.090,00$ \\
\hline 29 & $70.350,00$ & $71.610,00$ & $81.060,00$ \\
\hline 30 & $63.420,00$ & $64.470,00$ & $73.080,00$ \\
\hline 31 & $57.120,00$ & $57.960,00$ & $65.730,00$ \\
\hline 32 & $51.450,00$ & $52.290,00$ & $59.220,00$ \\
\hline 33 & $46.410,00$ & $47.040,00$ & $53.340,00$ \\
\hline
\end{tabular}


QUADRO 8 - Receita bruta estimada, em cruzeiros por hectare, nos blocos renovados pelo "Método sob Cacaueiros Decadentes", considerando-se a idade das plantas

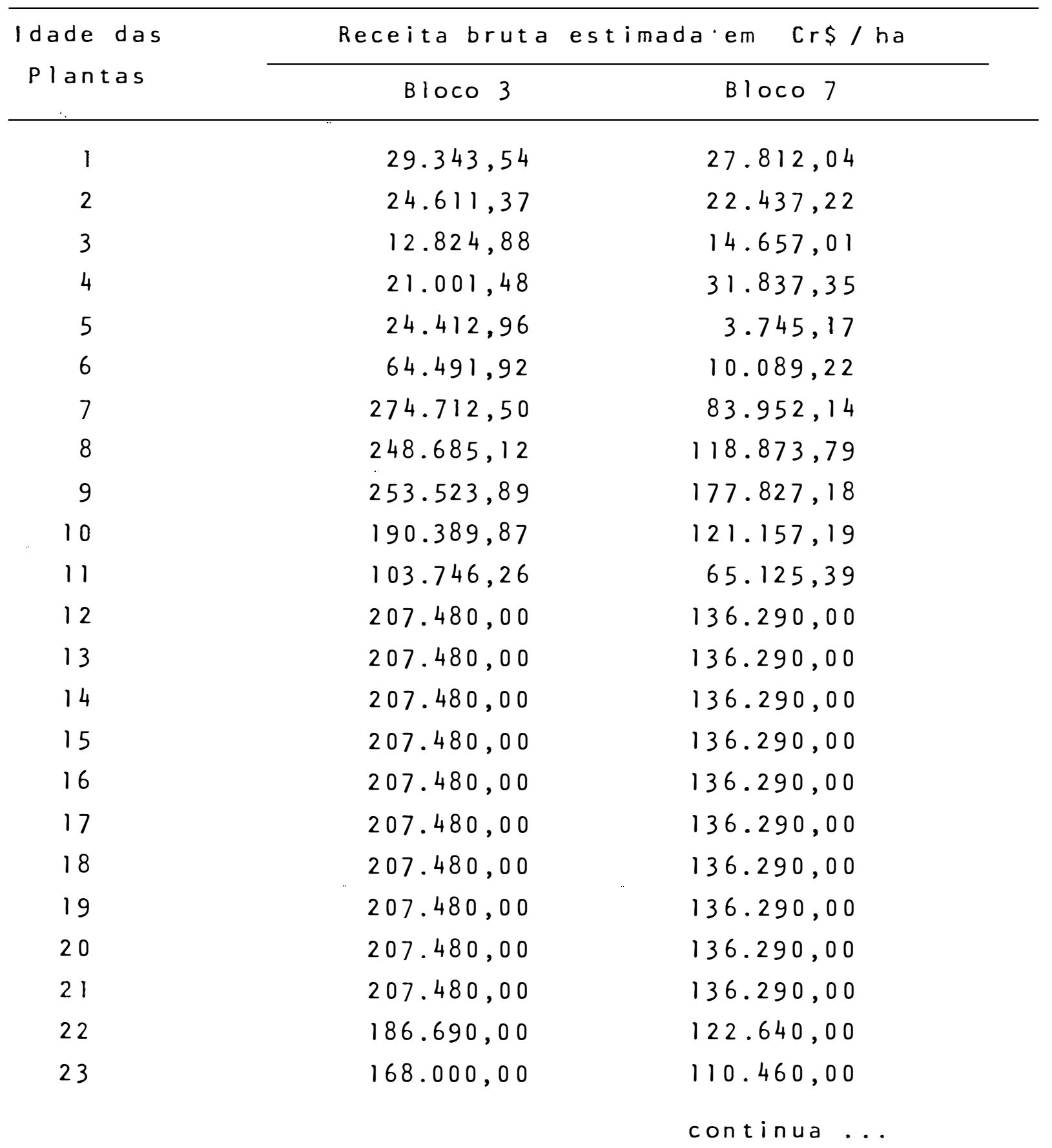


QUADRO 8 - Continuação

\begin{tabular}{ccc}
\hline Idade das & Receita bruta estimada em Cr\$ / ha \\
\cline { 2 - 3 } Plantas & Bloco 3 & Bloco 7 \\
\hline 24 & $151.200,00$ & $99.540,00$ \\
25 & $136.080,00$ & $89.670,00$ \\
26 & $122.430,00$ & $80.640,00$ \\
27 & $110.250,00$ & $72.660,00$ \\
28 & $98.700,00$ & $69.720,00$ \\
29 & $88.830,00$ & $62.790,00$ \\
30 & $80.010,00$ & $56.700,00$ \\
31 & $72.030,00$ & $51.030,00$ \\
32 & $64.890,00$ & $45.990,00$ \\
33 & $58.380,00$ & $41.370,00$ \\
\hline
\end{tabular}




\section{3 - Estimativa do Custo de Renovacão por Hectare}

A estimativa do custo de renovação de cacau,pa ra cada bloco, levou em consideração os gastos diretos com mão-de-obra, insumos, administração, encargos sociais e outras despesas com materiais de consumo. Não foi computada a inver são de capital em terras, benfeitorias e equipamentos, bem co mo as despesas com impostos e seguros, em razão da dificuldade de se avaliar satisfatoriamente esses custos.

Para determinar a corrente de custos resultante da inversão de capital em renovação de cacauais, levou - se em consideração a receita líquida que se deixa de receber com o corte das velhas plantações, mais os custos de implantação e manutenção das novas plantações, mais os custos de erradica ção dos cacaueiros velhos.

A receita líquida perdida decorrente da queda de produção pelo corte do cacaual decadente durante o pẹ ríodo inicial do processo de renovação foi calculada utilizan do-se a seguinte notação:

$$
R L P_{i}=Y \cdot P_{i}-G_{i}
$$

onde:

$$
\begin{aligned}
R L P_{i}= & \text { Receita líquida perdida no ano } \underline{i} ; \\
Y= & \text { Produção do ano anterior ao início do proces - } \\
& \text { so de renovação; } \\
P_{i}= & \text { Preço do produto no ano } \underline{i} ; \\
G_{i}= & \text { Gastos diretos com mão-de-obra nas operações } \\
& \text { de colheita, quebra, transporte e beneficia- } \\
& \text { mento do produto no ano } \underline{i} .
\end{aligned}
$$


Considerou-se a perda de receita líquida duran te os primeiros seis anos, período em que a produção dos cacaueiros novos foi menor do que a produção obtida dos cacaue ros velhos no ano anterior ao início do processo de renovação.

As receitas líquidas perdidas por hectare nos blocos renovado pelo "método de derruba total" encontram - se nos Quadros 9, 10 e 11 , enquanto os Quadros 12 e 13 apresen tam as receitas perdidas nos blocos renovados pelo "método sob cacaueiros decadentes".

Para calcular os custos de implantação e manutenção dos cacaueiros novos nos primeiros onze anos, levou-se em consideração os preços pagos pelos produtores (Anexos 2 e 3), e os coeficientes tëcnicos obtidos dos relatórios anuais da Fazenda Unitäria (MENDONÇA e ANDRADE FILHO, 1981). No que diz respeito a administração e outras despesas todos os valores foram deflacionados pelo Indice Geral de Preços da Fundação Getülio Vargas, no ano base $1980=100$.

Na apropriação dos custos nos anos subsequen tes, tomou-se como referência os preços da mão-de-obra e insu mos vigentes no ano de 1980 e as matrizes dos coeficientes téc nicos calculada a partir de dados dos relatórios anuais da Fa zenda Unitäria (Anexos 4 e 5).

Multiplicando-se as matrizes de coeficientes técnicos pelos preços de utilização da mão-de-obra e insumos, alēm dos custos de administração e outras despesas, obtiveram- 
se os custos de manutenção para o restante do ciclo de vida da cultura.

Os custos de erradicação dos cacaueiros deca dentes estão implícitos nas despesas efetuadas com mão-de-obra durante o período inicial do ciclo de renóvação.

Somando-se as receitas líquidas perdidas duran te os primeiros seis anos, aos custos de implantação e manuten ção obteve-se a corrente de custos por hectare, para cada bloco renovado, durante o ciclo de vida da cultura (Quadros 14 e 15).

Os elementos descritos compöem os custos do ci clo de renovação do projeto, lembrando que, tanto para o méto do de renovação com derruba total como para o método de renovação sob cacaueiros, os valores estimados nos primeiros seis anos correspondem ao período inicial de implantação do cultivo.

Os coeficientes técnicos das práticas agrícolas executadas na Fazenda Unitäria do CEPEC, obtidos a partir dos relatörios anuais, são equivalentes aos coeficientes técnicos determinados por TAFAN (1976) para um grupo de fazendas da Re gião Cacaueira da Bahia.

Considerando-se que os preços utilizados para o cálculo do custo foram aqueles vigentes na Região Cacaueira e que os coeficientes técnicos são equivalentes àqueles deter minados na Fazenda Unitäria, acredita-se que as estimativas dos custos desse trabalho aproximam-se bastante da realidade. 


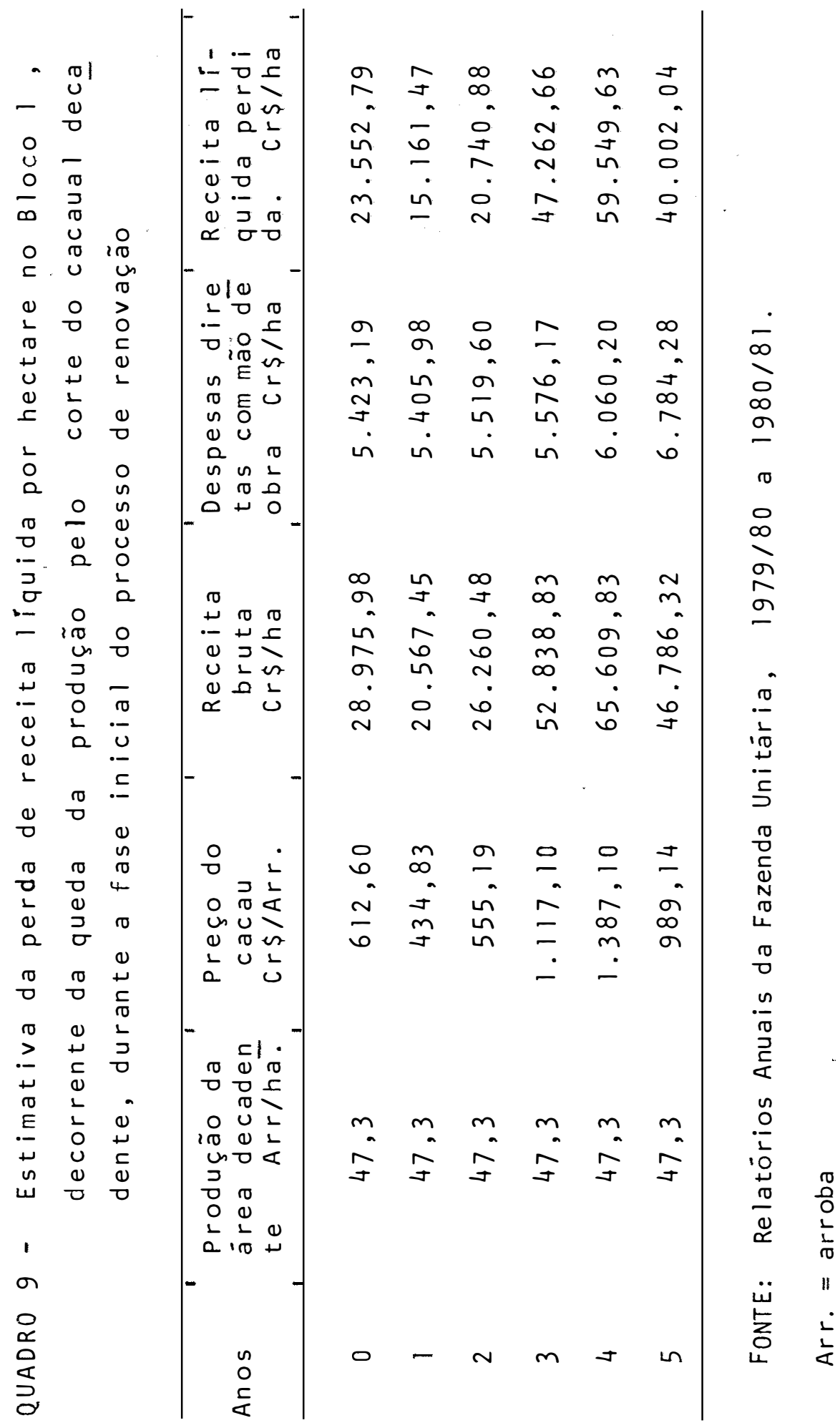


57.

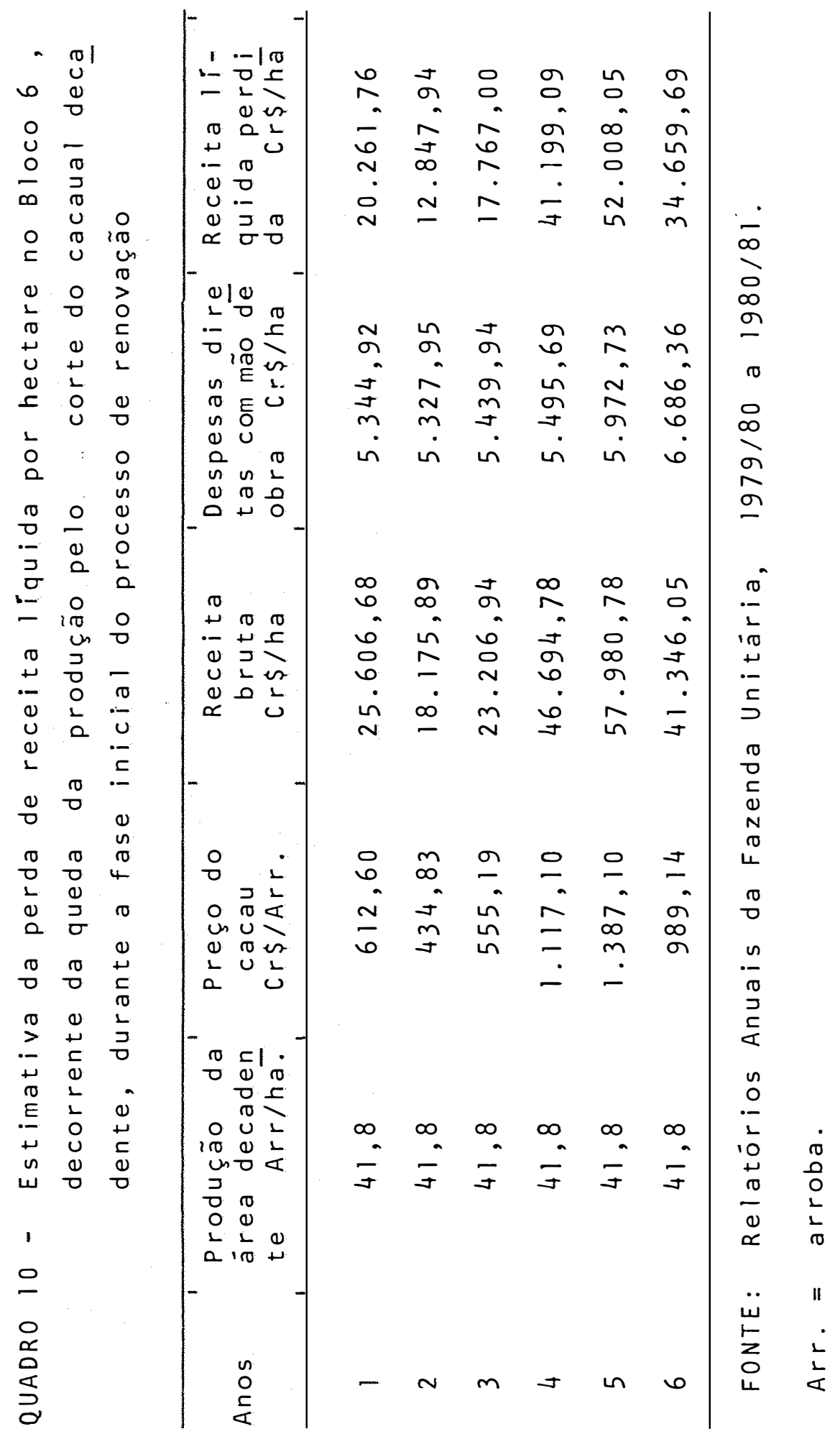


58.

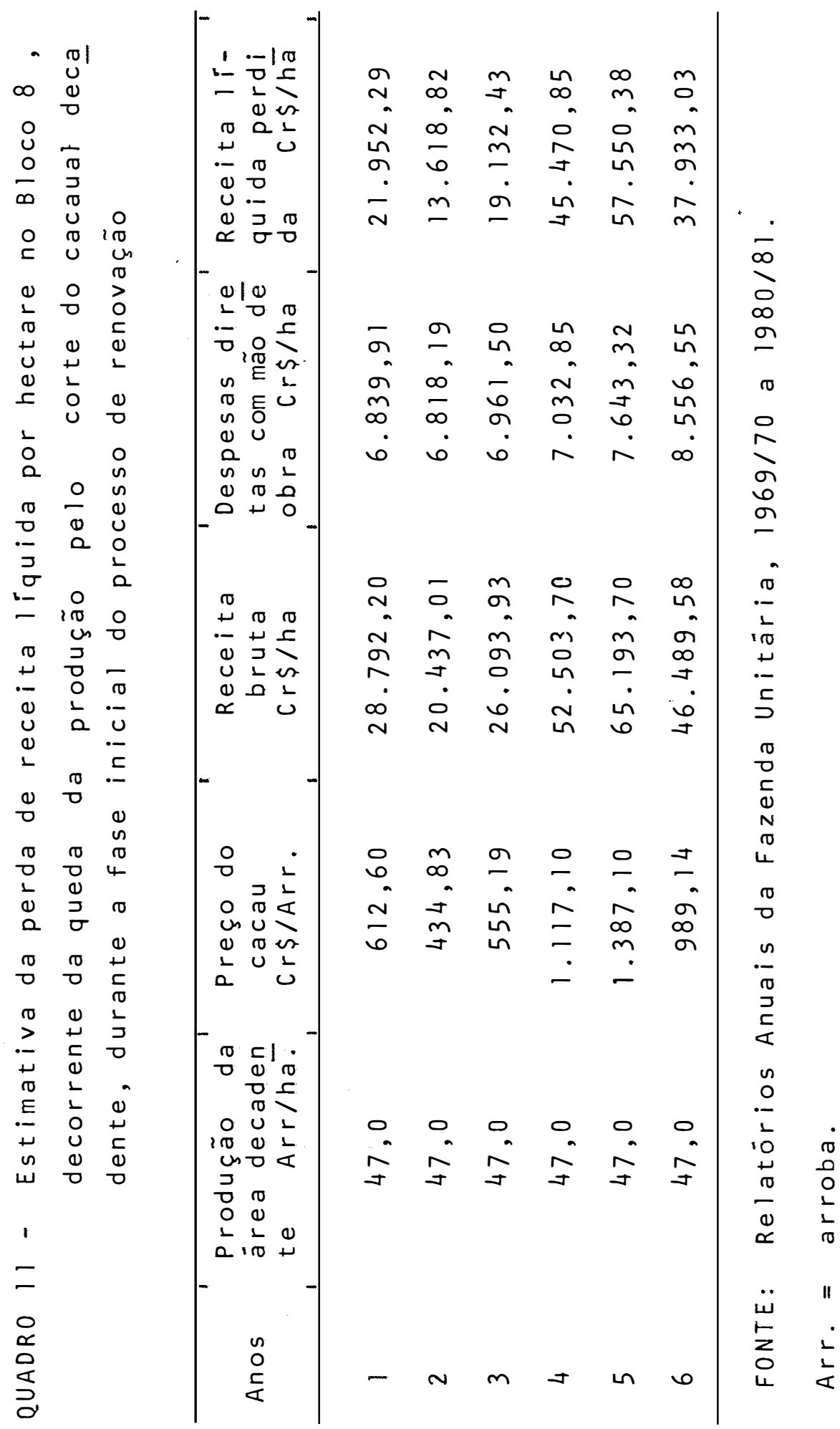




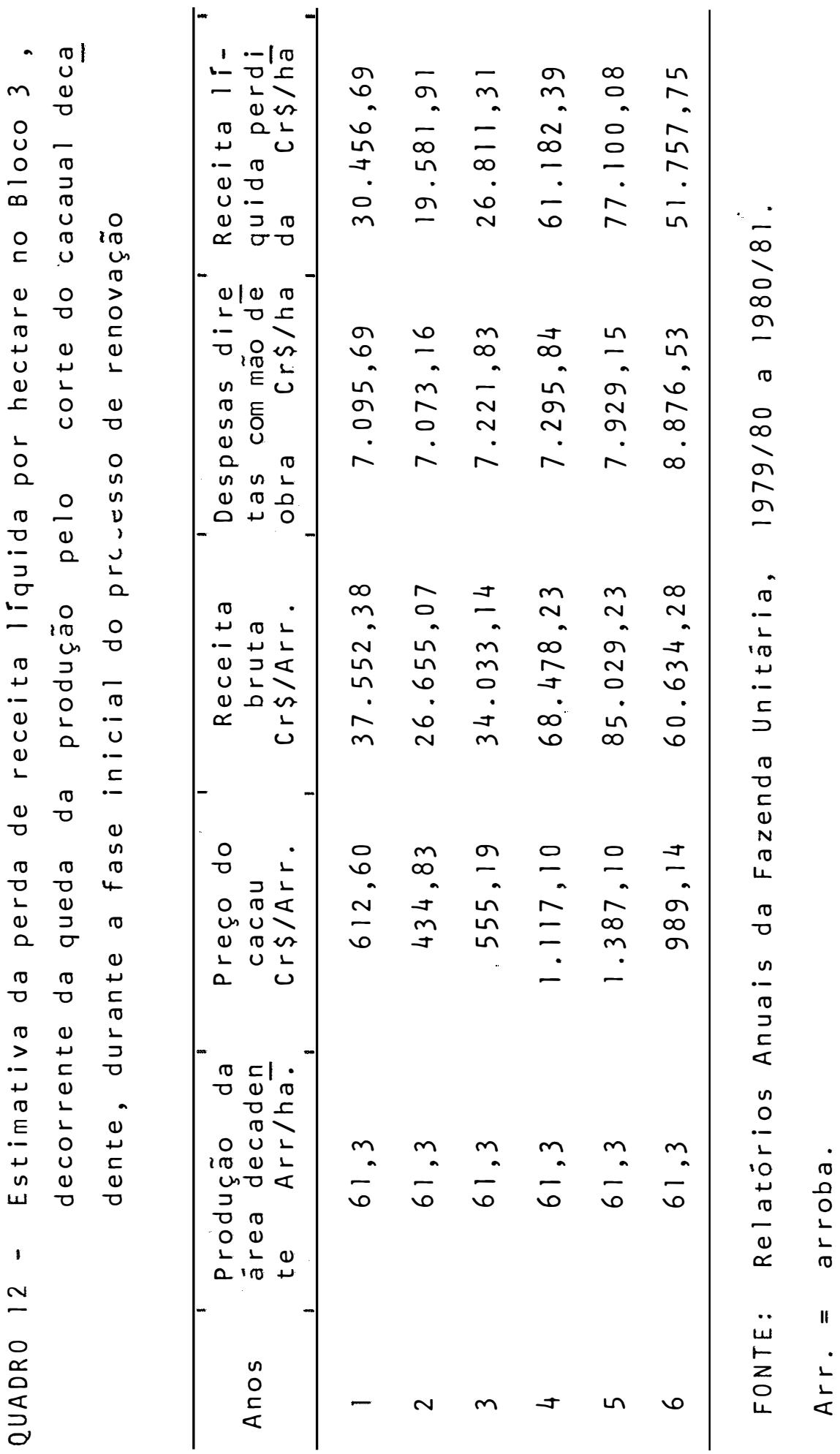




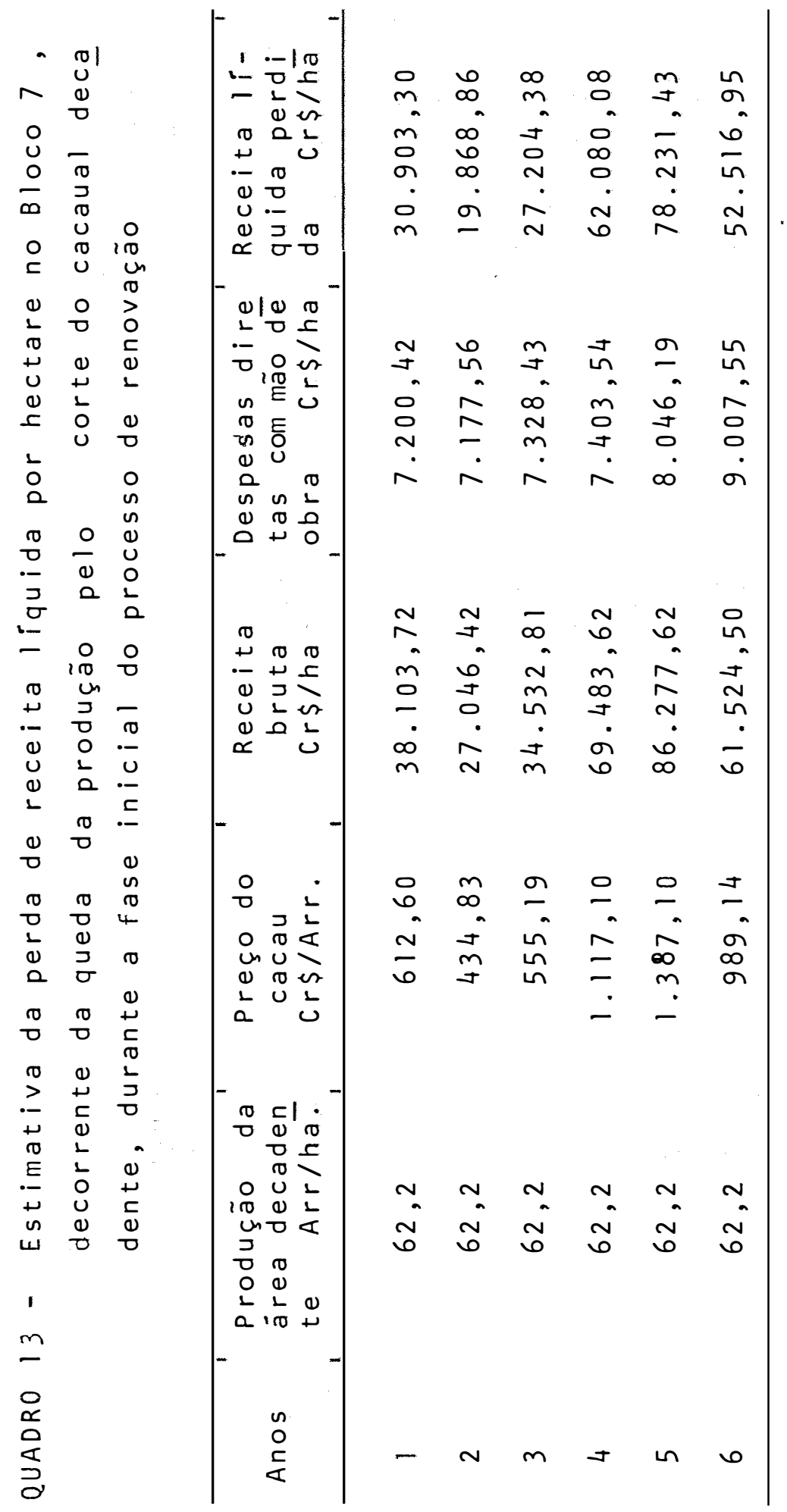


QUADRO 14 - Custos estimados, em cruzeiros por hectare, nos blocos renovados pelo "Método de Derruba Total', considerando-se a idade das plantas

\begin{tabular}{|c|c|c|c|}
\hline \multirow{2}{*}{$\begin{array}{l}\text { Idade das } \\
\text { Plantas }\end{array}$} & \multicolumn{2}{|c|}{ Custos estimados em } & \multirow{2}{*}{$\frac{\mathrm{Cr} \$ / \mathrm{ha}}{\text { Bloco } 8}$} \\
\hline & Bloco 1 & Bloco 6 & \\
\hline 1 & $27.419,51$ & $47.505,97$ & $12.913,40$ \\
\hline 2 & $41.348,12$ & $29.463,61$ & $33.605,49$ \\
\hline 3 & $29.951,64$ & $28.646,48$ & $33.302,25$ \\
\hline 4 & $29.311,85$ & $23.880,49$ & $21.063,84$ \\
\hline 5 & $26.923,37$ & $27.962,00$ & $33.126,83$ \\
\hline 6 & $37.733,65$ & $40.481,75$ & $22.708,86$ \\
\hline 7 & $95.133,91$ & $73.502,76$ & $44.334,95$ \\
\hline 8 & $67.051,17$ & $58.018,94$ & $64.931,92$ \\
\hline 9 & $103.004,15$ & $95.907,43$ & $103.690,56$ \\
\hline 10 & $116.367,54$ & $83.962,54$ & $108.698,13$ \\
\hline 11 & $84.110,78$ & $61.727,30$ & $55.887,85$ \\
\hline 12 & $60.553,56$ & $64.957,57$ & $72.003,96$ \\
\hline 13 & $60.553,56$ & $64.957,57$ & $72.003,96$ \\
\hline 14 & $60.553,56$ & $64.957,57$ & $72.003,96$ \\
\hline 15 & $60.553,56$ & $64.957,57$ & $72.003,96$ \\
\hline 16 & $60.553,56$ & $64.957,57$ & $72.003,96$ \\
\hline 17 & $60.553,56$ & $64.957,57$ & $72.003,96$ \\
\hline 18 & $60.553,56$ & $64.957,57$ & $72.003,96$ \\
\hline 19 & $60.553,56$ & $64.957,57$ & $72.003,96$ \\
\hline 20 & $60.553,56$ & $64.957,57$ & $72.003,96$ \\
\hline 21 & $60.553,56$ & $64.957,57$ & $72.003,96$ \\
\hline 22 & $57.735,00$ & $61.786,69$ & $67.776,12$ \\
\hline 23 & $55.092,60$ & $58.968,13$ & $64.076,76$ \\
\hline
\end{tabular}




$$
\text { QUADRO } 14 \text { - Continuação }
$$

\begin{tabular}{cccc}
\hline $\begin{array}{c}\text { Idade das } \\
\text { Plantas }\end{array}$ & \multicolumn{3}{c}{ Custos estimados em Cr\$/ha } \\
\cline { 2 - 4 } 24 & $53.154,84$ & $56.325,73$ & Bloco 8 \\
\hline 25 & $50.864,76$ & $54.035,65$ & $50.729,72$ \\
26 & $48.927,00$ & $51.921,73$ & $55.092,60$ \\
27 & $47.341,56$ & $50.160,13$ & $52.626,36$ \\
28 & $45.756,12$ & $48.398,53$ & $50.336,28$ \\
29 & $44.523,00$ & $46.813,09$ & $48.398,52$ \\
30 & $43.289,88$ & $45.403,81$ & $46.636,92$ \\
31 & $22.232,92$ & $44.170,69$ & $45.051,48$ \\
32 & $41.175,96$ & $43.113,73$ & $43.466,04$ \\
33 & $40.295,16$ & $42.506,27$ & $42.232,92$ \\
\hline
\end{tabular}


QUADRO 15 - Custos estimados, em cruzeiros por hectare, nos blocos renovados pelo "Método sob Cacaueiros De cadentes", considerando-se a idade das plantas

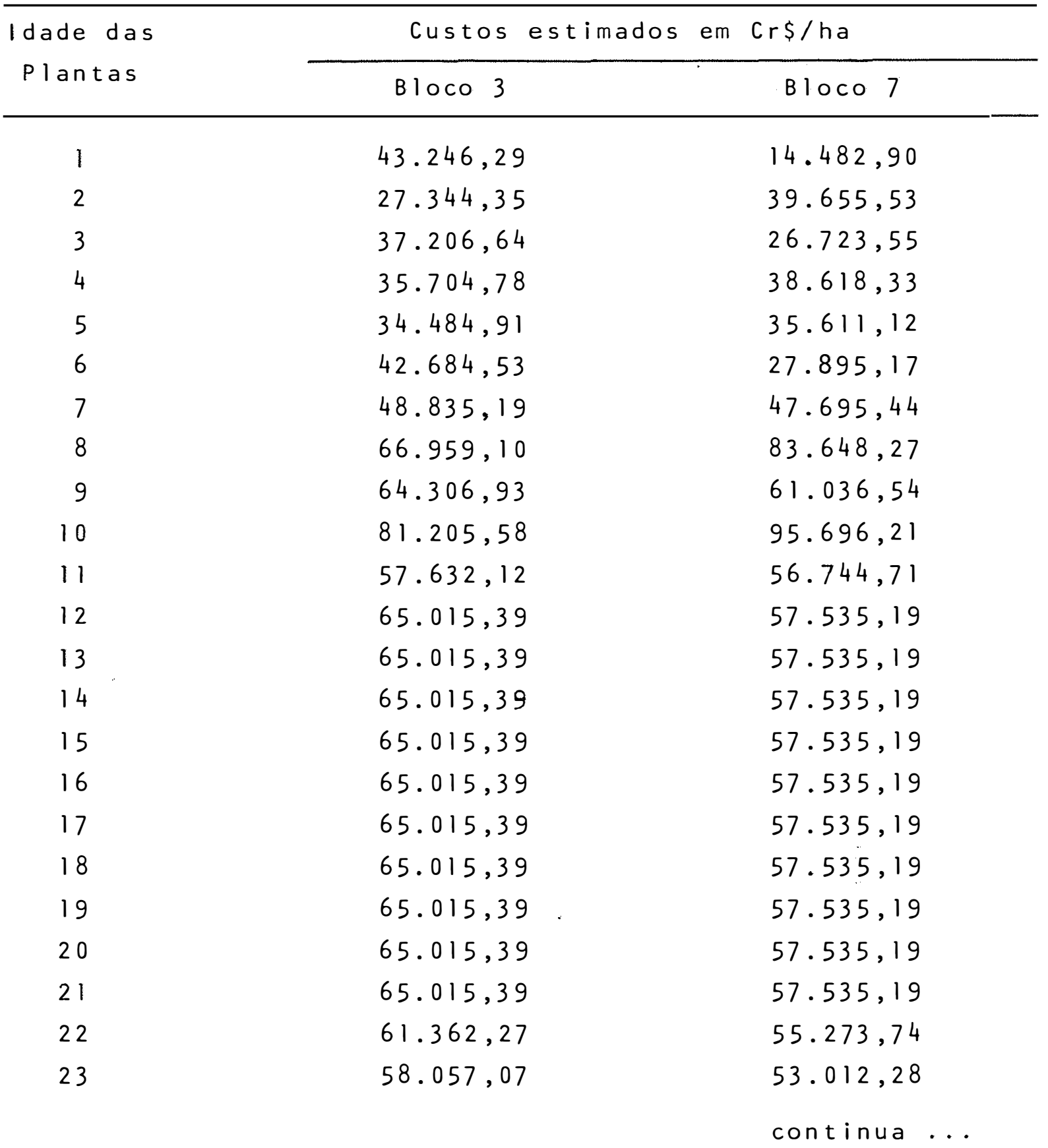


QUADRO 15 - Continuação

\begin{tabular}{ccc}
\hline Idade das & \multicolumn{1}{c}{ Custos estimados em Cr\$ /ha } \\
\hline & Bloco 3 & Bloco 7 \\
\hline 24 & $55.099,78$ & $51.272,70$ \\
26 & $52.490,41$ & $49.533,12$ \\
27 & $50.055,00$ & $47.967,50$ \\
28 & $47.967,50$ & $46.575,84$ \\
29 & $46.053,97$ & $46.053,96$ \\
30 & $44.314,37$ & $44.836,26$ \\
31 & $42.748,76$ & $43.792,51$ \\
32 & $41.357,10$ & $42.748,76$ \\
33 & $40.139,39$ & $41.878,97$ \\
\hline
\end{tabular}




\section{4 - Estimativa da Receita liquida por hectare}

$$
\text { As receitas líquidas anuais foram estimadas pẹ }
$$

la diferença entre as receitas brutas anuais e os custos anuais, através da seguinte notação

$$
F L=R B-\left(R L P+S_{v}+C_{n}\right)
$$

onde:

$$
\begin{aligned}
F L= & f l u x o \text { líquido anual por hectare; } \\
R B= & \text { receita bruta anual por hectare; } \\
\text { RLP = } & \text { receita líquida perdida por hectare, decorrente do } \\
& \text { corte do cacaual decadente no ano anterior ao ini - } \\
& \text { cio de processo de renovação; } \\
S_{V}= & \text { custo de erradicação do cacaual decadente; } \\
C_{n=} & \text { custo anual de implantação e manutenção das plantas } \\
& \text { novas; }
\end{aligned}
$$

A perda de receita líquida durante a fase inicial do processo de renovação é menor para o método de renova ção sob cacaueiros decadentes do que no método de renovação com derruba total, pois naquele método a erradicação das plan tas decadentes é feita de forma gradativa durante o período nicial do processo de renovação.

Assim, as receitas líquidas estimadas por hectare, em cada bloco renovado, apresentam-se nos Quadros 16 e 17. 
66.

QUADR0 16 - Receita liquida estimada, em cruzeiros por hectare, nos blocos renovados pelo "Método de Derruba Total", considerando-se a idade das plantas

\begin{tabular}{|c|c|c|c|}
\hline \multirow{2}{*}{$\begin{array}{l}\text { Idade das } \\
\text { Plantas }\end{array}$} & \multicolumn{3}{|c|}{ Receita liquida estimada em cruzeiros por hectare } \\
\hline & B $10 \mathrm{co} 1$ & B10co 6 & B10co 8 \\
\hline 1 & $-30.633,98$ & $-52.023,91$ & $-17.039,03$ \\
\hline 2 & $-55.813,87$ & $-42.311,55$ & $-20.177,89$ \\
\hline 3 & $-50.692,52$ & $-46.413,48$ & $-49.769,77$ \\
\hline 4 & $-76.574,51$ & $-65.079,58$ & $-66.534,69$ \\
\hline 5 & $-80.785,79$ & $-74.421,65$ & $-90.677,21$ \\
\hline 6 & $-45.588,64$ & $-32.905,17$ & $-60.641,89$ \\
\hline 7 & $94.967,14$ & $71.545,44$ & $-24.116,11$ \\
\hline 8 & $165.515,47$ & $142.310,74$ & $74.377,80$ \\
\hline 9 & $91.644,52$ & $93.214,18$ & $127.965,39$ \\
\hline 10 & $5.314,14$ & $48.733,43$ & $44.452,95$ \\
\hline 11 & $18.752,00$ & $41.135,48$ & $50.508,87$ \\
\hline 12 & $101.776,44$ & $100.312,43$ & $115.736,04$ \\
\hline 13 & $101.776,44$ & $100.312,43$ & $115.736,04$ \\
\hline 14 & $101.776,44$ & $100.312,43$ & $115.736,04$ \\
\hline 15 & $101.776,44$ & $100.312,43$ & $115.736,04$ \\
\hline 16 & $101.776,44$ & $100.312,43$ & $115.736,04$ \\
\hline 17 & $101.776,44$ & $100.312,43$ & $115.736,04$ \\
\hline 18 & $101.776,44$ & $100.312,43$ & $115.736,04$ \\
\hline 19 & $101.776,44$ & $100.312,43$ & $115.736,04$ \\
\hline 20 & $101.776,44$ & $100.312,43$ & $115.736,04$ \\
\hline 21 & $101.776,44$ & $100.312,43$ & $115.736,04$ \\
\hline 22 & $88.425,00$ & $87.103,31$ & $101.273,88$ \\
\hline 23 & $76.577,40$ & $75.011,88$ & $88.173,24$ \\
\hline & & & continua \\
\hline
\end{tabular}


QUADRO 16 - Continuação

\begin{tabular}{cccc}
\hline \multirow{2}{*}{$\begin{array}{c}\text { Plantas } \\
\text { Plas }\end{array}$} & \multicolumn{2}{c}{ Receita líquida estimada em cruzeiros por hectare } \\
\cline { 2 - 4 } & Bloco l & Bloco 6 & Bloco 8 \\
\hline 24 & $65.495,16$ & $64.424,27$ & $76.400,28$ \\
25 & $56.025,24$ & $54.744,35$ & $65.745,00$ \\
26 & $47.253,00$ & $45.938,27$ & $55.997,40$ \\
28 & $39.388,44$ & $38.039,87$ & $47.333,64$ \\
29 & $32.363,88$ & $30.981,47$ & $39.753,72$ \\
30 & $25.827,00$ & $24.796,91$ & $32.661,48$ \\
31 & $20.130,12$ & $19.066,19$ & $26.443,08$ \\
32 & $14.887,08$ & $13.789,31$ & $20.678,52$ \\
33 & $10.274,04$ & $9.176,27$ & $15.753,96$ \\
\hline
\end{tabular}




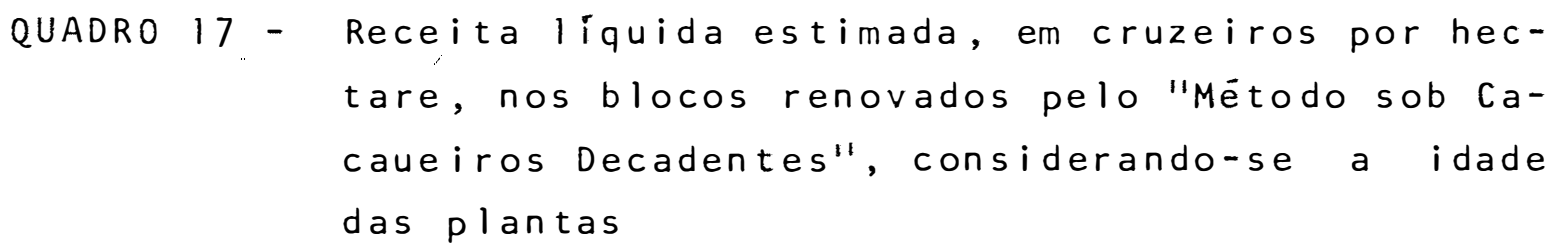

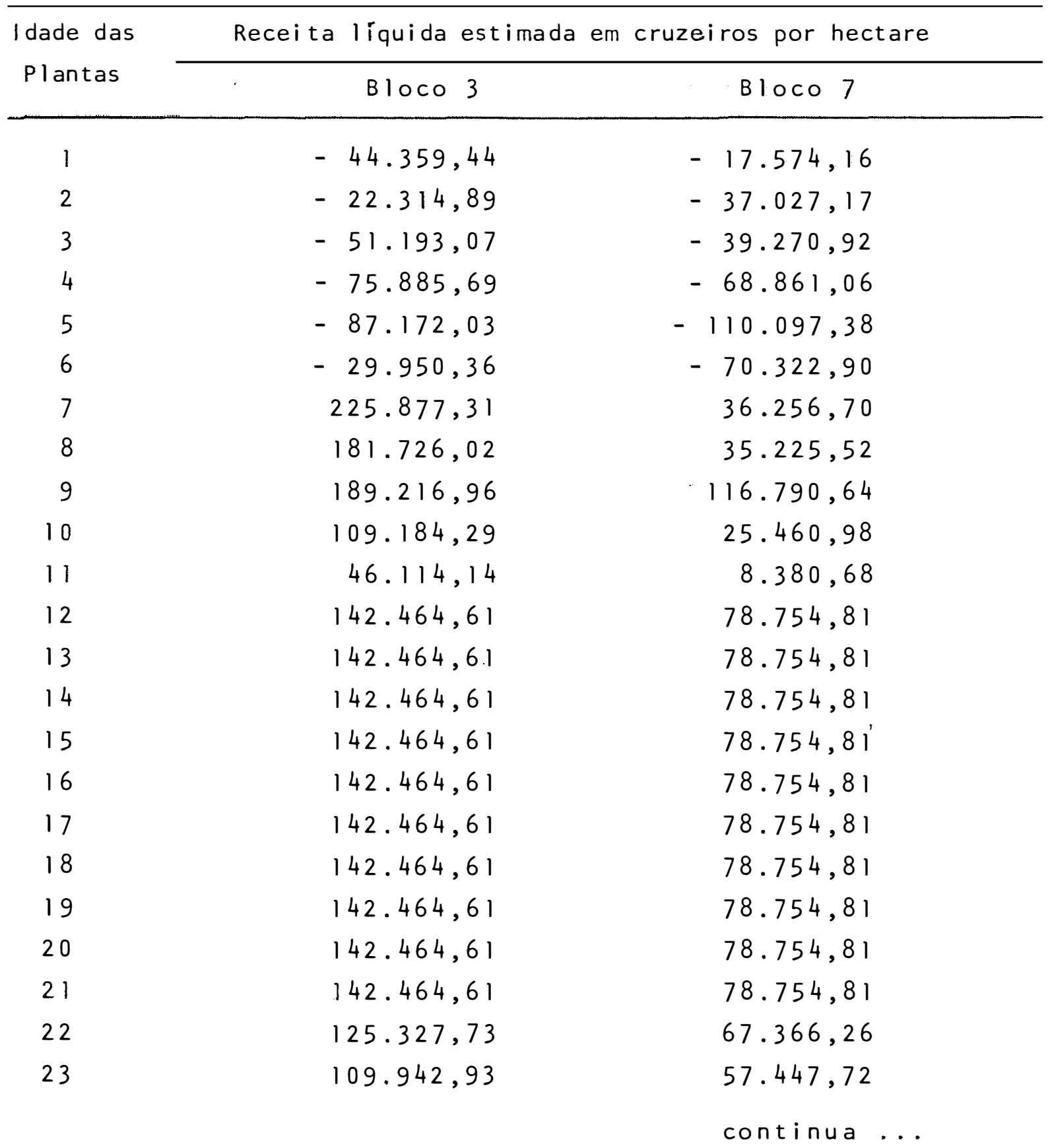


QUADRO 17 - Continuação

\begin{tabular}{ccc}
\hline Idade das & Receita líquida estimada em cruzeiros por hectare \\
\cline { 2 - 3 } Plantas & Bloco 3 & Bloco 7 \\
\hline 24 & $96.100,22$ & $48.267,30$ \\
25 & $83.589,59$ & $40.136,88$ \\
26 & $72.375,00$ & $32.672,50$ \\
27 & $62.282,50$ & $26.084,16$ \\
28 & $52.646,03$ & $23.666,04$ \\
29 & $44.515,63$ & $17.953,74$ \\
30 & $37.261,24$ & $12.907,49$ \\
31 & $30.672,90$ & $8.281,24$ \\
32 & $24.750,61$ & $4.111,03$ \\
& $19.458,31$ & 360,82 \\
\hline
\end{tabular}




\section{5 - Valor Atual da Receita Líquida Estimada}

Como vimos no Capítulo 3 , a principal limitaçäo para avaliar e selecionar projetos de investimento atravēs do critério do valor atual, reside na escolha da taxa relevante que deve ser empregada para descontar a corrente de re ceitas líquidas ao longo da vida económica do projeto.

A taxa de desconto relevante corresponde ao cus to de oportunidade do capital, que deve ser entendido como aquela taxa de retorno que è obtida pelos projetos de investimento mais rentäveis dentre aqueles que se deixa de realizar, devido o limitado volume de poupança disponível na economia.

Existem poucos estudos que procuram estimar a taxa de retorno ao capital privado na agricultura. Um caso a considerar foi o trabalho desenvolvido por TAFANI (1976) que encontrou uma taxa de retorno ao capital aplicado em cacau va riando entre 15 a $30 \%$, aproximadamente.

Em pesquisas realizadas com café, MATSUNAGA

(1981) optou por utilizar a taxa real de retorno obtida nos de pósitos de poupança, que foi de $6 \%$ ao ano, como referência pạ ra efeito de desconto dos fluxos de caixa ao longo do tempo.

Como não existe informações sobre a taxa inter na de retorno estimada para o setor agrícola como um todo, de terminou-se as rendas líquidas excedentes por hectare, em ter 
mos de cruzeiros de 1980, para os blocos renovados na fazenda Unitäria, usando-se taxas de desconto entre 0 e $30 \%$.

Admitindo-se que $12,5 \%$ a.a. seja a taxa relevante para remunerar os investimentos realizados em renovação de cacau, verifica-se que obloco 7 é considerado um projeto marginal, pois as taxas superiores apresentaria valor atual ne gativo, o que seria desinteressante do ponto de vista económi co. A essa taxa, o bloco 3 foi selecionado como o melhor pro jeto de investimento em renovação de cacauais, pois apresenta o maior valor atual do fluxo de receitas líquidas descontadas. 


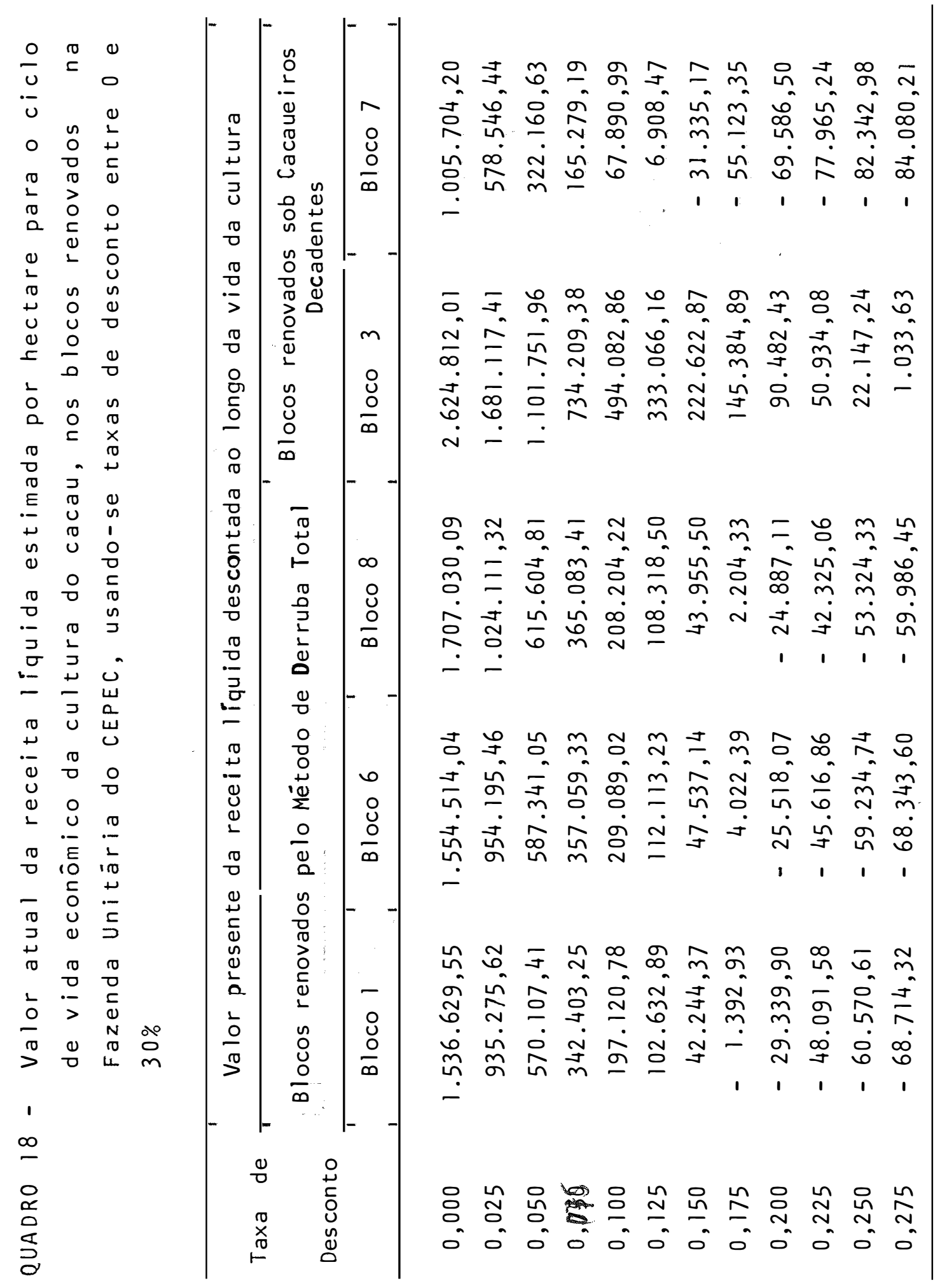


Quanto ao método de renovação com derruba total o bloco l apresentou valor atual positivo até quando se utiliza ra uma taxa de $15 \%$ ao ano, enquanto nos blocos 6 e 8 o ültimo valor atual positivo foi obtido a uma taxa de $17,5 \%$ ao ano.

Considerando que $12,5 \%$ seja a taxa relevante

que deva ser utilizada para descontar a corrente de receitas líquidas ao longo do ciclo de vida económica da cultura do ca cau, selecionou-se o bloco 3 , renovado pelo método sob cacaueiros decadentes, como a melhor alternativa de investimento em renovação de cacauais. No que se refere aos blocos renovados pelo método de derruba total, apesar de apresentarem valor atual inferior ao bloco 3 , podem ser considerados como uma boa opção de investimento.

\section{6 - Taxas Internas de Retornos Est imadas}

Os dados do Quadro 19 mostram as diferentes ta xas internas de retornos, obtidas para cada alternativa do pro jeto, tanto no método de renovação com derruba total como no método de renovação sob cacaueiros decadentes.

0 maior valor da taxa interna de retorno encon trada foi da ordem de $27,64 \%$ para o bloco 3 , renovado pelo méto do sob cacaueiros decadentes, enquanto o bloco 7 , também renovado por este método apresenta a menor taxa, 12,87\%, cons 
tituindo-se um projeto marginal quando se toma como referência para efeito de comparação, a taxa de $12,5 \%$ ao ano.

QUADRO 19 - Taxas internas de retornos estimadas por hectare para o ciclo de vida econômica da cultura do cacau, nos blocos renóvados na Fazenda Unitäria do CEPEC

\begin{tabular}{|c|c|c|c|}
\hline Método & $\begin{array}{l}\text { de renovação com der- } \\
\text { ruba total }\end{array}$ & Método & $\begin{array}{l}\text { novação sob ca- } \\
\text { os decadentes }\end{array}$ \\
\hline Blocos & Taxas de retornos & Blocos & Taxas de retornos \\
\hline Bloco 1 & $17,39 \%$ a.a. & Bloco 3 & $27,64 \%$ a.a. \\
\hline Bloco 6 & $17,78 \%$ a.a. & Bloco 7 & $12,87 \%$ a.a. \\
\hline Bloco 8 & $17,66 \%$ a.a. & & \\
\hline
\end{tabular}

os blocos 1,6 e 8 , renovados pelo método de derruba total, apresentaram taxas internas de retornos da ordem de $17,39 \%, 17,78 \%$ e $17,66 \%$, respectivamente.

As taxas internas de retornos obtidas nos blocos renovados pelo método de derruba total foram inferiores à taxa obtida no bloco 3 e superiores à taxa calculada para o bloco 7 , renovados pelo método sob cacaueiros decadentes.

Quando se compara o bloco 3 com os blocos 1 , 6 e 8 , verifica-se que o método de renovação sob cacaueiros 
decadentes apresentou resultados melhores do que o método com derruba total, ocorrendo o inverso quando se confronta a taxa obtida no bloco 7 com as dos blocos 1,6 e 8 .

Acredita-se que as diferenças verificadas entre as taxas internas de retornos, estejam associadas ao nível de produtividade alcançada em cada bloco, e que este nível de pro dutividade esteja diretamente relacionado à fertilidade dos so los predominantes em cada área, pois o montante de recursos a plicados durante o período inicial do processo de renovação fo ram equivalentes tanto para os blocos renovados pelo método de derruba total como para os blocos renovados sob cacaueiros de cadentes.

Por outro lado admite-se que uma redução no pre ço do cacau poderia encurtar o ciclo de vida econômica da cul tura e resultar numa diminuição da taxa interna de retorno. o inverso aconteceria no caso de um aumento no preço do cacau, desde que os custos prermanecessem os mesmos. Isto não impli caria uma mudança nos resultados de ordenação dos projetos pois, conforme o caso, reduziria ou elevaria todos os valores das taxas internas de retorno na mesma proporção.

Assim, através do critērio da taxa interna de retorno, verifica-se que a melhor alternativa de investimento em renovação de cacau refere-se ao bloco 3 , renovado pelo mé todo sob cacaueiros decadentes. 
Quanto ao método de renovação com derruba total os resultados permitem concluir que o investimento em renovação de cacau constitui um empreendimento interessante do ponto de vista económico, em todas alternativas analisadas, contudo o método de renovação por baixo ainda é mais interessante.

A comparação entre os dois mētodos de renova ção atravēs da taxa interna de retorno sobre os custos de FISHER, não permitiu selecionar a melhor alternativa de inves timento em renovação de cacau, pois as diferenças entre os flu xos de caixa dos projetos homólogos apresentaram alternância de sinal em todas as combinações estudadas, recaindo-se no prọ blema de múltiplas taxas internas de retorno. Isto decorreu do fato de não se verificar diferenças no montante de investi mento, entre os blocos analisados, durante o período inicial do processo de renovação.

Assim, a anälise de investimento em renovação de cacau apresentada neste trabalho, ficaram restritas aos resultados obtidos através do critērio do valor atual e da taxa interna de retorno. 


\section{5 - CONCLUSÕES}

As anälises realizadas permitiram concluir que tanto o critério do valor atual como o critério da taxa inter na de retorno conduziram à resultados semelhantes na avalia ção e seleção de projetos de investimento em renovação de ca$\mathrm{cau}$.

Admitindo-se que $12,5 \%$ seja a taxa relevante pera remunerar o capital investido em renovação de cacau, e sen do esta taxa equivalente a taxa mínima de retorno ao capital físico no Brasil, estimada por LANGONI (1974), verifica-se que a inversão de capital em renovação de cacau constitui uma ati vidade atrativa do ponto de vista econômico em todas alternativas analisadas.

A comparação entre os dois métodos de renovação mostrou que os blocos renovados pelo método de derruba total 
apresentaram resultados inferiores ao bloco 3 e superiores ao bloco 7 , renovados pelo método sob cacaueiros decadentes.

Os resultados sugerem que a alternância verifi cada na seleção e ordenação de projetos, quando se compara os dois métodos de renovação, esteja associada ao nível de prodü tividade alcançada em cada bloco devido as diferenças de drenagem e fertilidade dos solos, pois o montante de recurso aplicados durante o período inicial do processo de renovação foi equivalente tanto para os blocos renovados pelo método de derruba total como para os blocos renovados sob cacaueiros decadentes. Isto ficou evidenciado pelos resultados alcançados no bloco 7 .

Verificou-se que tanto o bloco 3 como o bloco 7 estão localizados em solos da sērie produção, de alta ferti lidade natural, e considerado um dos melhores solos para cacau, dentre aqueles existentes na Fazenda Unitäria. Apesar disso, observou-se que o bloco 7 apresentou o menor retorno ao investimento realizado em renovação de cacau, em decorréncia dos baixos rendimentos físicos alcançados, devido a um proble ma de drenagem imperfeita da àrea onde se encontra instalado. Tanto o critério do valor atual como o critério da taxa interna de retorno selecionou o bloco 3 como a melhor alternativa do investimento em renovação de cacauais, enquanto os blocos renovados pelo método de derruba total foram con siderados um empreendimento interessante do ponto de vista e- 
conômico, em todas alternativas analisadas.

Não se verificou diferenças no montante de recursos aplicados, entre os blocos renovados, durante o período inicial do processo de renovação e a alternância de sinal apresentada pela diferença entre os fluxos de caixa de dois projetos homólogos, resultou em mültiplas taxas internas de re torno não permitindo concluir a respeito da seleção do melhor projeto de investimento em renovação de cacau, pela taxa interna de retorno sobre os custos de FISHER.

Assim, a anälise de investimento em renovação de cacau ficou limitada aos resultados obtidos através do cri tērio do valor atual e da taxa interna de retorno, calculada para cada bloco experimental.

Os resultados alcançados permitem concluir que a rentabilidade dos projetos não foi a causa responsável pelo lento desempenho do programa de renovação de cacauais nos ültimos cinco anos, pois a inversão de capital em renovaçäo de cacau constituiu uma atividade atrativa em todas alternativas analisadas.

Por outro lado, o crëdito parece näo ter sido um fator limitante ao desempenho do programa, devido a oferta abundante, a facilidade de acesso e de custo altamente subsi di ado . 
Com base nos resultados alcançados neste trabä lho, supõe-se que existam outras causas que impediram alcan çar as metas propostas pelo programa de renovação de cacauais no Sul da Bahia.

Nos últimos cinco anos verificou-se uma elevação acentuada nos preços do cacau, o que permitiu um maior uso de tecnologia do tipo químico-biológico, elevando o rendimento de áreas que anteriormente eram antieconómicas, levando os agricultores a adiarem a renovação dessas áreas.

Supõe-se que os subsídios dado ao programa de renovação de cacauais não tenha sido suficiente para estimular os agricultores, o que poderia ter deslocado sua atenção para implantação em detrimento da renovação. 


\section{6 - LITERATURA CITADA}

ALVARES AFONSO, F. M., et alii, 1974. Renovação de cacauais como investimento e considerações sobre nivelamento de cus tos e receitas. Cacau Atualidades, 13(1)_ 12-20.

ALVARES AFONSO, F. M., 1967. Problemas de administração rural na replantação de cacauais: 0 primeiro ano de traba Tho com a Fazenda Unitāria de Cacau, em La Lola, Costa Rica. Instituto Interamericano de Ciēncias Agrícolas da 0. E.A., Turrialba, Costa Rica, 167 p. (Tese de M.S.).

Alvares AFONSO, F. M., 1969. Estudo comparativo de dois métodos de renovação de cacauais, através da técnica da Fazenda Unitāria. Relatōrio Anual da Fazenda Unitāria Sem pre Viva e Moroziana. Itabuna, CEPLAC. (mimeografado).

ALVIM, P. T. e M. ROSARIO, 1972. Cacau, Ontem e Hoje. Itabuna, CEPLAC. $83 \mathrm{p}$. 
BACHA, E. L., et alii, 1974. Anālise governamental de proje toso de investimento no Brasil: procedimentos e recomenda ções. 2? ed., Rio de Janeiro, IPEA/INPES. 206 p.

COMISSAO EXECUTIVA DO PLANO DA LAVOURA CACAUEIRA, Brasilia, 1977. Diretrizes para Expansão da Cacauicultura Nacional 1976/1985. $200 \mathrm{p}$.

COMISSAO EXECUTIVA DO PLANO DA LAVOURA CACAUEIRA, Itabuna, 1971. Programa de renovação de cacauais decadentes. 2. ed., $47 \mathrm{p}$.

FUNDAÇAOO GETOLIO VARGAS, 1979. Conjuntura Econōmica, Rio de Janeiro, 33(9): 67-79.

FUNDAÇAO GETOLIO VARGAS, 1980. Conjuntura Econōmica, Rio de Janeiro, 34 $(6)$ : 93-103.

FARO, C. de, 1971. Critérios quantitativos para avaliação e seleção de projetos de investimentos. Rio de Janeiro, IPEA/INPES, $142 \mathrm{p}$.

FERREIRA, H. I. S., 1977. A renda cessante em renovação de cacaueiros: Anālise de uma estratégia. Fortaleza. Uni versidade Federal do Ceará, 84 p. (Tese de M.S.).

FONSECA, M. A. S. da, 1976. Retorno social aos investimen tos em pesquisa na cultura do café. Piracicaba, ESALQ/ USP, 148 p. (Tese de M.S.).

FROTA, P. C. E., 1974. Notas sobre o clima da região cacaueira bahiana. Cacau Atualidades, 11(3): 18-20 
GARCIA, J. R., 1974. Porque estā aumentando a produção de cacau no sul da Bahia. Cacau Atualidades, 11(3): 18-20.

GILL and DUFFUS, 1981. Cocoa Market Report, 294: $25 \mathrm{p}$.

JOLLY, A. L., 1957. The Unit Farm as a Toal in Farm Manegement Research. Journal of Farm. Economics, 39(3): $739-744$.

LANGONI, C. T., 1974. As causas do crescimento econōmico do Brasil. Rio e Janeiro, APEC, $120 \mathrm{p}$.

LOPEZ Neto, A. S. e AGUiRRe, J. A., 1971. Anālise econōmico de los costos de replantacion de cacao. Turrialba, Costa Rica. (Publicación Micelanea, nọ 88). 24 p.

LOPEZ, R. G. H., 1950. Comportamiento de los brotos en el arbal de cacao despues de la poda. Turrialba, Costa Ri $\mathrm{ca}, 37 \mathrm{p}$.

MATSUNAGA, M., 1981. Alternativas tecnológicas na cultura do café no Estado de São Paulo. São Paulo, USP. 160 p. (Tese de M.S.).

MENDONÇA, N. C. e ANDRADE FILHO, E. A., 1981. Relatórios anuais da Fazenda Unitāria do CEPEC: Período de 1970/71 1980/81. Divisão de Socieconomia do CEPEC. (não publicados).

MENEZES, J. A. S., 1972. Produtividade e taxa marginal de re torno de insumos modernos em Fazendas de Cacau, Regiāo Ca caueira da Bahia, Ano Agrícola 1971/1972. Viçosa, U.F.V. Imprensa Universitāria, $85 \mathrm{p}$. (Tese de M.S.). 
MENEZES, J. A. S., 1974. Resultado económico de renovação de cacauais: Um estudo de caso. Cacau Atualidades: 11 (3): $2-7$.

MONTEIRo, A., 1976. Avaliação econōmica da pesquisa e extensão agrícola: 0 caso do cacau no Brasil, Viçosa, $U$. F.V., Imprensa Universitāria, $78 \mathrm{p}$. (Tese de M.S.).

MORICOCHI, L., 1980. Pesquisa e Assistência Técnica na Citricultura: Custos e retornos sociais. Piracicaba, ESALQ/ USP, 84 p. (Tese de M.S.).

SANTOS, U., 1976. A renovação de cacauais e o cacauiucultor: Um estudo de atitude. Itabuna. Boletim Técnico no $36.15 \mathrm{p}$.

SILVA, L. F. e A. A. O. MELO, 1970. Levantamento detalhado dos solos do Centro de Pesquisas do Cacau. Itabuna, Boletim Técnico nọ $7,89 \mathrm{p}$.

TAFANI, R. R., 1976. Avaliação econōmica da introdução de novas tecnologias na cultura do cacau no Brasil. Viçosa, U.F.V., Imprensa Universitāria, 148 p. (Tese de Ph.D.).

TAFANI, R. R., 1976. Especulacion teorica sobre decisiones de inversion en cultivos perenes, caso del cacao. I tabu na, Boletim Técnico nọ $39,31 \mathrm{p}$.

VASCONCELOS, A. ; M. H. ALENCAR e H. I. S. FERREIRA, 1972. Novo programa de renovação de cacauais na Bahia. In: $4^{\text {th }}$ Internation Cocoa Research Conference. Trinidad and Tabago. 
85.

7-A HEXOS 


\begin{abstract}
ANEXO 1 - Preço médio recebido pelo produtor de cacau no periodo de 1970 a 1980. Todos os valores foram corrigidos utilizando-se o Indice Geral de Preços da Fundação Getūlio Vargas, com base em $1980=100$.
\end{abstract}

\begin{tabular}{lcc}
\hline Anos & $\begin{array}{c}\text { Valornominal } \\
\text { Cr/arroba }\end{array}$ & $\begin{array}{c}\text { Valor real } \\
\text { Cr\$aroba } \\
\text { Base }\end{array}$ \\
\hline 1970 & 26,67 & 612,60 \\
1971 & 22,79 & 434,83 \\
1972 & 34,04 & 555,10 \\
1973 & 83,07 & $1.117,10$ \\
1974 & 126,10 & $1.387,10$ \\
1975 & 114,75 & 989,14 \\
1976 & 360,28 & $2.197,70$ \\
1977 & 672,50 & $2.878,30$ \\
1978 & 780,22 & $2.403,07$ \\
1979 & 874,15 & $1.748,30$ \\
1980 & $1.262,12$ & $1.262,12$ \\
\hline
\end{tabular}

FONTE: Relatörios Anuais da Fazenda Unitäria do CEPEC $1969 / 70$ a $1980 / 81$.

Fundação Getūlio Vargas. Conjuntura Econômica 1979 e 1980 . 
ANEXo 2 - Preço diário da mão-de-obra no período de 1970 a 1980. Todos os valores foram corrigidos utili zando-se o Indice Geral de Preços da Fundação Ge túlio Vargas, com base em $1980=100$.

\begin{tabular}{lcc}
\hline Anos & $\begin{array}{c}\text { Valor nominal } \\
\text { Cr\$/homem-dia }\end{array}$ & $\begin{array}{c}\text { Valor real } \\
\text { Cr\$ } / \text { homem-dia } \\
\text { Base: } 1977=100\end{array}$ \\
\hline 1970 & 4,80 & 110,25 \\
1971 & 5,76 & 109,90 \\
1972 & 6,88 & 112,21 \\
1973 & 8,00 & 113,36 \\
1974 & 11,20 & 123,20 \\
1975 & 16,00 & 137,92 \\
1976 & 22,70 & 138,47 \\
1977 & 37,40 & 160,07 \\
1978 & 52,00 & 160,16 \\
1980 & 110,05 & 220,10 \\
\hline
\end{tabular}

FONTE: Relatörios Anuais da Fazenda Unitäria do CEPEC $1969 / 70$ a $1980 / 81$. Fundação Getúlio Vargas, Conjuntura Econômica 1979 e 1980. 
ANEXO 3 - Preço médio anual dos principais insumos usados na Fazenda Unitäria do CEPEC no período de 1970 a 1980. Valores corrigidos utilizando-se o Indice Geral de Preços da. Fundação Getūlio Vargas, com base em $1980=100$.

\begin{tabular}{|c|c|c|c|c|}
\hline Anos & $\begin{array}{l}\text { Tordon- } 101 \\
(1 \mathrm{itro})\end{array}$ & $\begin{array}{c}\text { Cobre Sandoz } \\
\text { (saco de } 25 \\
\text { kg) }\end{array}$ & $\begin{array}{l}\text { BHC } \\
\left(\begin{array}{c}\text { saco de } 25 \\
\text { kg })\end{array}\right.\end{array}$ & $\begin{array}{l}\text { Adubo - NPK } \\
\text { (saco de } 25 \mathrm{~kg})\end{array}$ \\
\hline & \multicolumn{4}{|c|}{ (Valores reais) } \\
\hline 1970 & 422,64 & $2.756,40$ & 140,30 & 620,19 \\
\hline 1971 & 486,54 & $1.621,80$ & 138,33 & 496,08 \\
\hline 1972 & 489,30 & $1.957,20$ & 126,40 & 570,85 \\
\hline 1973 & 425,10 & $1.700,40$ & 129,94 & 559,72 \\
\hline 1974 & 357,50 & $1.650,00$ & 194,37 & $1.182,50$ \\
\hline 1975 & 431,00 & $2.376,96$ & 301,70 & 989,48 \\
\hline 1976 & 469,70 & $2.406,45$ & 259,25 & 705,95 \\
\hline 1977 & 385,20 & $2.247,00$ & 267,50 & 629,63 \\
\hline 1978 & 338,80 & $2.025,84$ & 226,99 & 617,41 \\
\hline 1979 & 384,00 & $2.247,82$ & 230,00 & 624,44 \\
\hline 1980 & 352,91 & $2.429,29$ & 214,33 & 780,71 \\
\hline
\end{tabular}

FONTE: Divisão de Socioeconomia do CEPEC. Dados não publicados. Fundação Getūlio Vargas. Conjuntura Econômica 1979 e 1980 . 
ANEXO 4 - Coeficientes técnicos necessärios para manutenção anual de um hectare de cacaueiros safreiros nos blocos renovados pelo "Método de Derruba Total"

\begin{tabular}{|c|c|c|c|c|c|c|c|}
\hline & & & ef & entes $t$ & èc & $i \cos$ & \\
\hline & Itens & Bloco & 1 & Bloco & 6 & Bloco $\varepsilon$ & 8 \\
\hline 1 & $\begin{array}{c}- \text { Mão-de-obra (Homens/ } \\
\text { Dia): }\end{array}$ & & & & & & \\
\hline & $\begin{array}{l}\text { Colheita, quebra e trans- } \\
\text { porte de cacau mole }\end{array}$ & 0,71 & & 0,86 & & 0,85 & \\
\hline & - Beneficiamento & 0,33 & & 0,30 & & 0,47 & \\
\hline & - Roçagem & 38,00 & & 39,00 & & 31,00 & \\
\hline & - Combate às pragas & 0,50 & & 0,50 & & 0,50 & \\
\hline & - Adubação & 8,00 & & 8,00 & & 8,00 & \\
\hline & Desbrota & 4,00 & & 4,00 & & 4,00 & \\
\hline & - Poda & 12,00 & & 11,00 & & 13,00 & \\
\hline & Escoramento de cacaueiros & 2,00 & & 4,00 & & 4,00 & \\
\hline & Limpesa de drenos & 7,00 & & 7,00 & & 6,00 & \\
\hline & - Transporte de materiais & 1,00 & & 1,00 & & 1,00 & \\
\hline 2 & - Materiais & & & & & & \\
\hline & - Adubo NPK: saco $50 \mathrm{~kg}$ & 5,00 & & 5,00 & & 5,00 & \\
\hline & $\begin{aligned} \text { Inseticida } B \text { B C : } & \text { saco } \\
& 25 \mathrm{~kg}\end{aligned}$ & 1,00 & & 1,00 & & 1,00 & \\
\hline & - Combustivel: litro & 0,50 & & 0,50 & & 0,05 & \\
\hline 3 & - Administração & $20,00 \%$ & + & $20,00 \%$ & + & $20,00 \%$ & + \\
\hline 4 & $\begin{array}{l}\text { - Outros gastos de pes- } \\
\text { soal }\end{array}$ & $40,00 \%$ & + & $40,00 \%$ & * & $40,00 \%$ & * \\
\hline
\end{tabular}

FONTE: Relatōrios Anuais da Fazenda Unitäria do CEPEC $1969 / 70$ a $1980 / 81$.

(*) Percentagens calculadas sobre os custos de mão-de-obra e materiais. 
ANEXO 5 - Coeficientes técnicos necessärios para manutenção anual de um hectare de cacaueiros safreiros nos blocos renovados pelo "Método sob Cacaueiros Deca dentes"

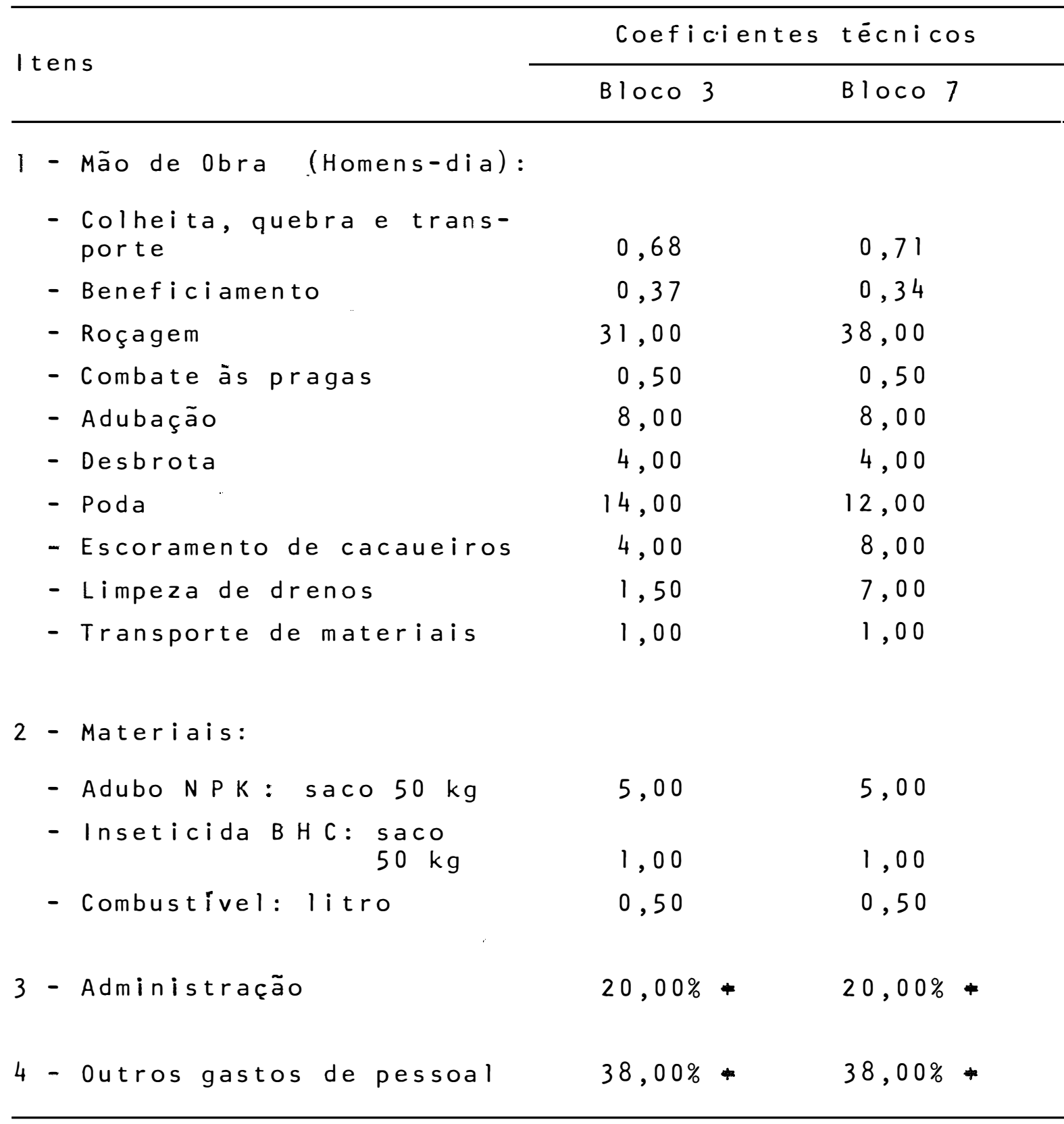

FONTE: Relatórios Anuais da Fazenda Unitäria do CEPEC $1969 / 70$ a $1980 / 81$.

(*) Percentagens calculadas sobre os custos de mão-de-obra e materiais. 